OPEN ACCESS

Edited by:

Nicolas Venteclef,

Sorbonne Universités, France

Reviewed by:

Andrew C. B. Cato,

Karlsruhe Institute of Technology

(KIT), Germany

Dino Moras,

INSERM U964 Institut de Génétique et de Biologie Moléculaire et Cellulaire (IGBMC), France

*Correspondence: Lars Grøntved larsgr@bmb.sdu.dk

tThese authors have contributed equally to this work

Specialty section

This article was submitted to Molecular and Structural Endocrinology,

a section of the journal

Frontiers in Endocrinology

Received: 15 June 2020

Accepted: 03 September 2020 Published: 08 October 2020

Citation:

Præstholm SM, Correia CM and Grøntved L (2020) Multifaceted Control of GR Signaling and Its Impact on Hepatic Transcriptional Networks and Metabolism.

Front. Endocrinol. 11:572981.

doi: 10.3389/fendo.2020.572981

\section{Multifaceted Control of GR Signaling and Its Impact on Hepatic Transcriptional Networks and Metabolism}

\author{
Stine M. Præstholm ${ }^{\dagger}$, Catarina M. Correia ${ }^{\dagger}$ and Lars Grøntved ${ }^{*}$ \\ Department of Biochemistry and Molecular Biology, University of Southern Denmark, Odense, Denmark
}

Glucocorticoids (GCs) and the glucocorticoid receptor (GR) are important regulators of development, inflammation, stress response and metabolism, demonstrated in various diseases including Addison's disease, Cushing's syndrome and by the many side effects of prolonged clinical administration of GCs. These conditions include severe metabolic challenges in key metabolic organs like the liver. In the liver, GR is known to regulate the transcription of key enzymes in glucose and lipid metabolism and contribute to the regulation of circadian-expressed genes. Insights to the modes of GR regulation and the underlying functional mechanisms are key for understanding diseases and for the development of improved clinical uses of GCs. The activity and function of GR is regulated at numerous levels including ligand availability, interaction with heat shock protein (HSP) complexes, expression of GR isoforms and posttranslational modifications. Moreover, recent genomics studies show functional interaction with multiple transcription factors (TF) and coregulators in complex transcriptional networks controlling cell type-specific gene expression by GCs. In this review we describe the different regulatory steps important for GR activity and discuss how different TF interaction partners of GR selectively control hepatic gene transcription and metabolism.

Keywords: Glucocorticoid receptor, chromatin, transcription, metabolism, liver

\section{INTRODUCTION}

Any living organism must adapt and respond to the surrounding environment to maintain its existence. For multicellular organisms such as mammals, this includes daily transitions between different physiological conditions including sleep/awake, fasted/fed, and physical inactivity/activity. Moreover, occasional response to environmental changes such as confinement, predator stress, extreme temperatures, inflammation and prolonged lack of food is critical for survival. Glucocorticoids (GCs) serve as important endocrine signaling molecules controlling many molecular signaling pathways that enable cells in the organism to respond to different extrinsic cues. This is particularly evident for cellular responses in the arousal state including the transitions mentioned above. Importantly, pathophysiological conditions leading to dysfunctional GC signaling have dramatic effects on many important biological functions including development, inflammatory response, reproduction, cognitive function, anxiety, circadian entrainment, cardiovascular regulation and cellular metabolism in a tissue-specific manner (1). For example, 
uncontrolled GC secretion observed in Cushing's syndrome leads to metabolic complications such as type 2 diabetes and osteoporosis, which are also observed in situations of prolonged treatment with GCs. In contrast, conditions of low GC production, seen in Addison's disease, are associated with muscle weakness, low blood pressure and weight loss (2).

Glucocorticoids exert their actions primarily by binding to the glucocorticoid receptor (GR or $\mathrm{Nr} 3 \mathrm{cl}$ ), which is expressed in most cells in mammals. Yet, GCs have highly tissue/cellspecific effects regulated by multiple mechanisms. As a DNAbinding transcription factor (TF), GR is primarily involved in the control of gene expression, with transcription of GR target genes in a given cell being controlled by three overall mechanisms (Figure 1). First, activity of GR is directly correlated with the amount of GC molecules available in the cell. This is controlled by adrenal GC synthesis and local availability of GCs in the cell. Second, expression of active GR in the nucleus determines the molecular response to GCs. This is regulated by GR turnover (synthesis and breakdown), expression of different GR isoforms, posttranslational modifications (PTMs) and nuclear translocation. Third, genomic action of GR is controlled by cell type-specific accessibility of GR response elements (GRE) in the genome in synergy with cell-specific TFs, coregulators and regulatory RNAs. In this review we will discuss all three regulatory aspects of GR signaling with a specific focus on GR interaction with the genome. We will primarily refer to studies from mouse liver tissue to discuss recent insights to hepatic gene regulatory networks and metabolism controlled by GCs. This will specifically be related to the hepatic transcriptional response to the circadian rhythm, feeding and fasting.

\section{REGULATION OF GLUCOCORTICOID SECRETION AND AVAILABILITY IN THE CELL}

Glucocorticoids (cortisol in humans; corticosterone in rodents) are steroid hormones secreted circadianly by the adrenal cortex. Their daily levels peak immediately before the active phase (early morning for humans; early evening for rodents) in anticipation of a waking state, but also in quick response to external stimuli such as stress, hypoglycemia and exercise $(3,4)$. The hypothalamicpituitary-adrenal (HPA) axis controls and maintains GC secretion into the bloodstream (Figure 1A). The hypothalamus

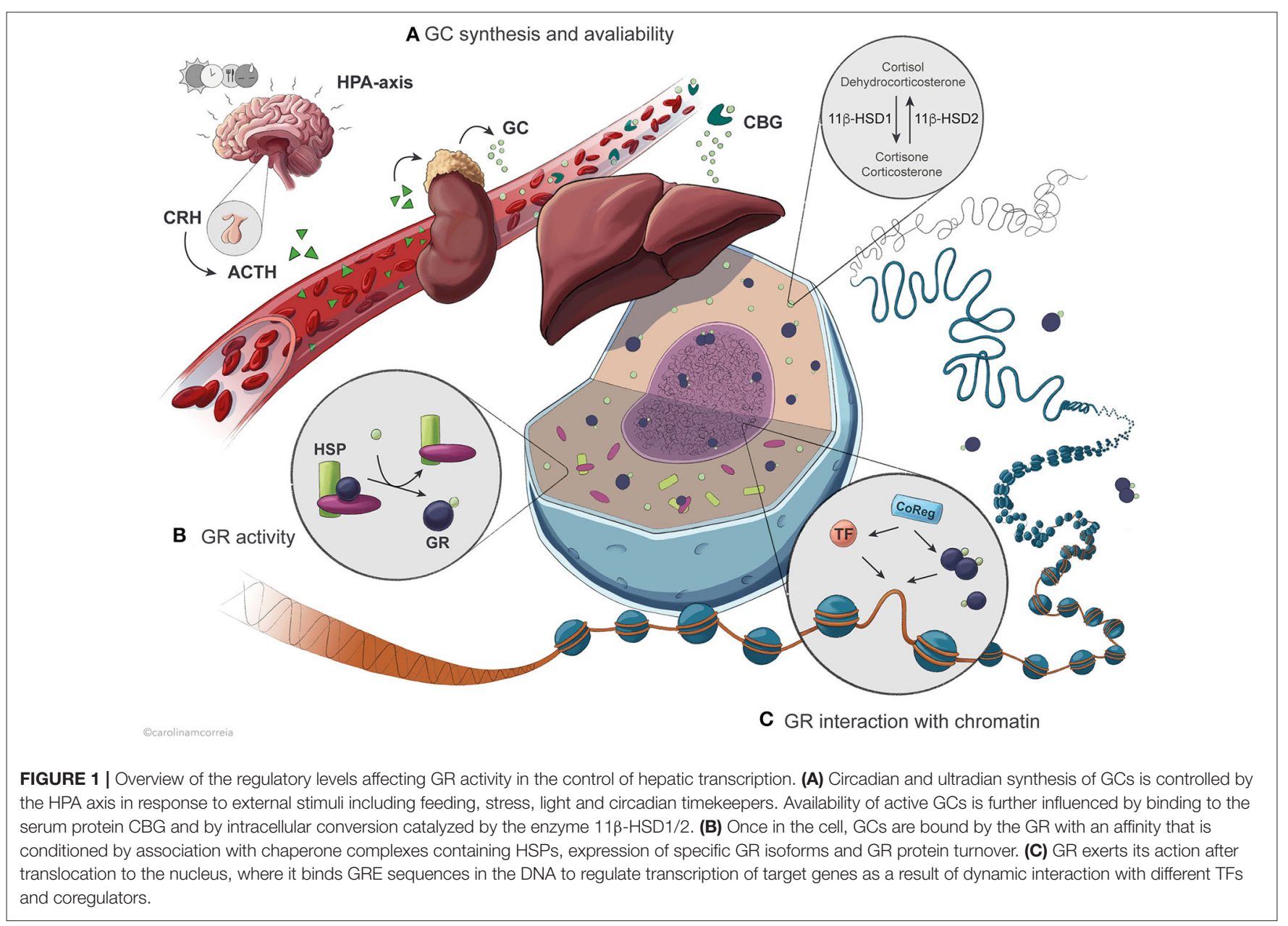


produces corticosteroid-releasing hormone $(\mathrm{CRH})$, stimulating the pituitary gland to secrete adrenocorticotropic hormone $(\mathrm{ACTH})$, which in turn promotes GC secretion by the adrenal gland (5). As many other hormones, including growth hormone and insulin $(6,7)$, GCs are secreted in an ultradian pattern with pulsatile secretion once every 60 to $90 \mathrm{~min}$, as a result of feedback and feedforward mechanisms between $\mathrm{ACTH}, \mathrm{CRH}$ and GC secretion keeping GC levels in a physiological range $(4,8,9)$. The circadian secretion of GCs results partly from oscillations in ACTH secretion, but mostly from varying adrenal sensitivity to ACTH (3-5). In the blood, GCs circulate in association with corticosteroid-binding globulin (CBG) or, to a lower extent, albumin, and only a small fraction remains unbound in most vertebrates. As only free GCs diffuse into the target cells, CBG modulates GC bioavailability (10-12). Disruption of CBG expression in mice leads to reduced total serum GC (13) and as CBG and albumin are synthesized by the liver, it is possible that hepatic regulation of GC-binding proteins modulates the levels of available GC.

Additionally, non-adrenal production of cortisol has been described in visceral adipose tissue and liver via the conversion of inert cortisone catalyzed by the enzyme $11 \beta$ hydroxysteroid dehydrogenase type 1 (11 $\beta$-HSD1) in humans (dehydrocorticosterone to corticosterone in rodents), and reversely by $11 \beta$-HSD2 $(14,15)$ (Figure 1A). Liver activity of this enzyme is particularly relevant to the whole-body nonadrenal production of cortisol; however, HPA axis feedback mechanisms likely blunt any systemic effects (15). Therefore, activity of $11 \beta$-HSD1 mostly contributes to locally maintaining intracellular levels of active GCs in the liver and visceral adipose tissue, fine-tuning the highly variable GC levels. This enzyme thus regulates the availability of receptor-active GCs in the cell, modulating access to GR and amplifying GC effects (16-18). In mice, absence of $11 \beta$-HSD1 leads to an inability to produce active GCs from the inert form, resulting in compensatory activation of the HPA axis, increased basal corticosterone levels and failure to fully elicit a hepatic gluconeogenic response to fasting, similarly to absence or impairment of GR (19). Dysregulation of $11 \beta$-HSD1 expression and activity is associated with apparent hypercortisolemia, disrupted metabolism and HPA axis function, obesity, type 2 diabetes and metabolic syndrome; however, the specific contribution of the enzyme to these processes is still controversial $(16,18)$.

\section{CIRCADIAN CONTROL OF GLUCOCORTICOID LEVELS}

The circadian synthesis and secretion of GCs by the adrenal glands is controlled by both the local molecular clock and the central clock in the suprachiasmatic nucleus (SCN) via a sympathetic neuronal pathway, and can be blunted by stress stimuli $(3,4)$. The SCN is important for GC rhythmicity, as it regulates the hypothalamic-hypophysial portions of the HPA axis affecting CRH secretion (20-22). During light-induced HPA axisindependent GC secretion, the SCN directly activates the adrenal glands via the adrenal sympathetic nerves, suggesting that GCs can act as SCN-gated mediators of the light stimuli to entrain metabolic-responsive peripheral clocks (5). The ubiquity of GR expression and the marked circadian secretion of GCs imply that these are efficient SCN-driven synchronizers of peripheral clocks and, specifically in the liver, are fundamental for the circadian expression of metabolic genes, even with contribution from other hormonal signals and entrainment factors (3, 4, 23). However, GCs do not affect the central clock, since GR is not expressed in the $\operatorname{SCN}(3,23)$.

Unlike the SCN, the phase of peripheral clocks can be modulated by feeding, and even uncoupled from the SCN (3). As a metabolic organ, the liver is particularly responsive to feeding patterns, which can lead to desynchronization of its peripheral clock from the central clock $(24,25)$, an entrainment partly mediated by GCs (26-29). The interplay between eating behavior and GCs can be observed during day-restricted feeding of mice (opposite to their normal feeding pattern), leading to secretion of GCs with two distinct peaks instead of a single one, with one being feeding-responsive (before feeding time, in the early morning) and the other light-entrained (before the normal active period, in the early evening) (3, 4, 27, 30). Misalignment also occurs as a result of the disruption of normal activity patterns due to jet lag, shift work, sleep disorders or social jet lag, and associates with the development of metabolic disorders, such as diet-induced obesity and non-alcoholic fatty liver disease (31).

\section{GR STRUCTURE, SPLICE VARIANTS AND PTMS IN THE MODULATION OF GR ACTIVITY}

The effects of GCs are mediated by GR through its three functional domains: a hydrophobic C-terminal ligand-binding domain (LBD) containing a ligand-dependent trans-activation portion ( $\tau_{2}$, or AF2), a zinc-finger DNA-binding domain (DBD) located adjacently, and an $\mathrm{N}$-terminal trans-activation domain $\left(\tau_{1}\right.$, or AF1) (32-34). There is extensive alternative splicing and translation of human GR, impacting cell-specific GC actions. Alternative splicing originates multiple isoforms varying primarily in the $\mathrm{DBD}$ and the C-terminal $\mathrm{LBD} / \mathrm{AF} 2$, while multiple translational start sites give rise to GR proteins with different lengths of the AF1 domain. The expression of some GR isoforms is evolutionarily conserved, but while many have shown biological relevance in humans (35), isoforms in rodents are less characterized. In humans and rodents, GR $\alpha$ (referred to simply as GR henceforth) is considered the canonical GR isoform that mediates most actions of GCs and is the primary isoform expressed in most tissues. Alternative splicing of the GR primary transcript in humans and rodents can give rise to additional GR isoforms, including GR $\beta$, which has a truncated C-terminus, resulting in an inactive AF2, with compromised ability to bind GCs. Thus, GR $\beta$ is considered dominant negative $(36,37)$. Although expressed to a lower level than GR $\alpha$, GR $\beta$ is considered a functional TF in a number of tissues, including the liver $(36,38)$. Additional isoforms include the widely expressed GR $\gamma$, which exhibits similar affinities to both GCs and DNA as $\mathrm{GR} \alpha$, but has a compromised transactivation potential and is 
associated with GC resistance. Expression of GR is also affected by the activity of miRNA molecules that bind to the $3^{\prime}$ UTR of GR transcripts, affecting their stability and preventing their translation (37). Additionally, lncRNAs such as Gas5 repress ligand-activated GR activity by binding to its $\mathrm{DBD}$ as a decoy GRE in starvation conditions, leading to suppression of GCstimulated mRNA expression of key gluconeogenic enzymes G6Pase and Pck1 during fasting (39).

In addition to the coregulatory function of specific GR isoforms, the activity of hormone-bound GR in different tissues can be modulated by specific sets of PTMs (40). For example, upon hormone binding, ligand-selective phosphorylation of the GR affects GR-mediated transcriptional activity and recruitment of coregulators, and is thus involved in directing and modulating GR action as a repressor or activator, namely via crosstalk from other signaling pathways such as in GSK3 $\beta$-mediated phosphorylation (40-45). The relevance of PTMs on the GR protein and their effects on GR function are also illustrated by the protein-protein interactions between clock components and GR leading to suppression of GR activity via acetylation of a lysine residue by the CLOCK protein, potentiated by the presence of BMAL1 (46). Additionally, modifications such as GC-dependent phosphorylation reduce GR stability and halflife by tagging it for ubiquitination and subsequent degradation, and also influence its subcellular localization (37, 43, 44, 47-49). Other PTMs affecting GR function include SUMOylation, which reduces protein stability and regulates transcriptional activity, as well as nitrosylation and oxidation, both associated with reduction of GC-binding (37).

\section{REGULATION OF GR TRANSLOCATION TO THE NUCLEUS}

Inactive GR is located in the cytoplasm, monomerically associated with a multimeric chaperone complex important for GR stability, folding and translocation (Figure 1B). The maturation of the complex involves a stepwise ATP-dependent assembly from the initial GR-HSP70-HSP40 complex, to the recruitment of HSP90 and Hop facilitating the assembly of a final high GC affinity complex consisting of GR, HSP90, p23, and FKBP51 (50). Circulating GCs enter the cells via diffusion across the cell membrane and interact with GR. Upon ligand-binding, a FKBP51-FKBP52 switch exposes the GR nuclear localization signals, which are recognized by importins and nucleoporins, facilitating the translocation of activated GR through a nuclear pore via microtubules $(50,51)$. Disruption of FKBP52 leads to reduced expression of GR target genes in the liver and augmented hepatic steatosis as a result of diet-induced obesity (52), also observed in liver-specific GR knock out (L-GRKO) mice (26), demonstrating a functional role of the multimeric chaperone complex for hepatic GR function. In general, the subcellular location of GR follows the diurnal GC concentration (53). However, both ligand-bound and unbound GR shuttle dynamically between the nucleus and the cytoplasm with a variable rate, consequently regulating GR activity. Aberrantly high cytosolic $\mathrm{pH}$ and chemical stress can lead to dissociation of HSP90 and increased nuclear import of GR. GR nuclear translocation can also be regulated by context-specific PTMs, e.g., phosphorylation of GR by kinases like MAPKs, CDK, and GSK3 (50). In the liver, factors including HDAC6 and REV-ERB $\alpha$ have been found to affect GR translocation, thus affecting GR activity $(53,54)$.

\section{GENOMIC ACTIONS OF GR: GENERAL CONCEPTS}

Following nuclear translocation, GR accumulates at specific gene regulatory regions (e.g., enhancers) depending on the DNA sequence, occupancy of other TFs, organization of nucleosomes and higher order chromatin structures (Figure 1C). GR residence time at specific regions of chromatin lasts seconds, whereas freely diffusing unbound GR occupies chromatin in milliseconds (55) (Figure 2A). This enables GR to efficiently probe tens of thousands of putative enhancers within a short time frame and initiate transcription of hundreds of genes within minutes of activation by hormone (56). Also, the dynamic nature of chromatin interaction is shared by transcriptional coregulators known to interact with GR (57), both likely playing an important kinetic role in GC-regulated gene expression, including the duration and frequency of transcriptional bursting (58). As a result of the pulsatile secretion pattern, GC concentration in the serum is highly dynamic, allowing a rapid transcriptional response that can be translated into a fast biochemical response (59). For example, transcriptional bursting has been linked to a fast-acting metabolic switch in hepatic glucose metabolism, where expression of gluconeogenic genes such as G6pc and Pck1 is rapidly decreased in response to feeding (60), the latter being regulated by GCs $(61,62)$.

\section{Direct and Indirect GR Interaction With the DNA Template}

Genomic occupancy of GR is facilitated by direct GR binding to GREs on DNA as a monomer, homodimer or tetramer (63) (Figure 2B), with the tetrameric structure being suggested as the final active form of GR (64). GR binds directly to the canonical DNA motif consisting of inverted repeats separated by 3 bps (nGnACAnnnTGTnCn) or to half-sites of these inverted repeats (nGnACA) $(63,65)$ and degenerate versions of these $(66)$. In addition, GR can bind other inverted repeats separated by $0-2$ bps (CTCC(n) $)_{0-2}$ GGAGA) $(67,68)$, termed negative GREs (nGRE). Besides binding directly to DNA, GR can occupy enhancers by tethering to DNA-bound TFs by protein-protein interactions $(63,65)$.

Binding of GR to canonical DNA motifs as homodimers and tetramers is generally associated with GC-mediated transactivation $(63,69-71)$. Also, studies suggest that GR association with GR half-sites is linked to active gene expression $(63,65)$. Once GR is associated with enhancers, GCinduced transactivation involves recruitment of transcriptional coactivators to facilitate chromatin remodeling, histone hyperacetylation and mediator recruitment which leads to recruitment and/or increased activity of RNA polymerase II 




B

\section{Canonical GRE:}

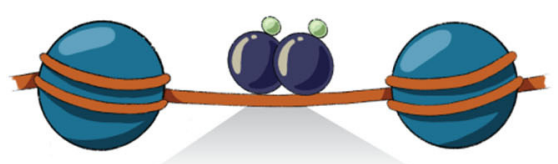

nGnACAnnnTGTnCn

nGRE:

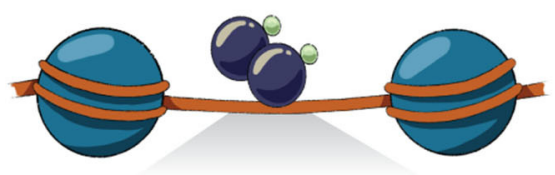

CTCC(n)0-2GGAGA
Half GRE:

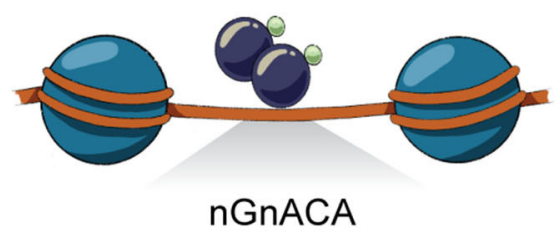

Tethering:

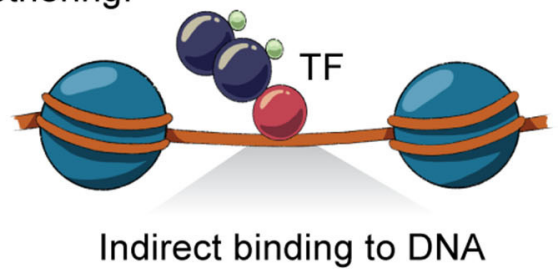



FIGURE 2 | Direct and indirect GR-DNA interactions. (A) GR interacts dynamically with DNA. Freely diffusing GR occupies chromatin with residence time in milliseconds, whereas GR binding at specific regions of chromatin is measured in the order of seconds. (B) GR interacts directly with DNA by binding to canonical GRE (nGnACAnnnTGTnCn), half-sites (nGnACA) and nGRE (CTCC(n) ${ }_{0-2}$ GGAGA) or indirectly by tethering to DNA-bound TFs by protein-protein interactions. (C) TFs can assist the loading of GR, or vice versa, by facilitating an accessible chromatin environment at the regulatory site.

at juxtaposed gene promoters $(56,72-74)$. In contrast, GCmediated transrepression has been widely discussed, and hence several different models have been presented, including direct binding of GR to nGRE motifs, interaction with DNA sequences bound by other TFs, tethered GR binding to transactivating TFs, redistribution of monomeric $\mathrm{GR}$, sequestering of transactivating coregulators and/or GR-regulated expression of negative modulators of transcription (75). Even though nGREs have been associated with transcriptional repression $(67,68,76)$, their role has been debated $(63,72,74)$. For example, recent studies found no enrichment of nGREs at enhancers juxtaposed to GC-repressed genes (74). In contrast to enhancers induced by GC, repressed enhancers show marginal canonical GR binding motifs, suggesting that GR binds other DNA motifs (77) or 
tethers to other TFs (78). This type of GR interaction with DNA is generally believed to be mediated by monomeric GR, based on structural studies of the GR DBD and mice expressing a mutant GR $\left(\mathrm{GR}^{\mathrm{dim}}\right)$ unable to achieve DBD dimerization $(69,76-79)$. Although mice expressing $\mathrm{GR}^{\mathrm{dim}}$ indeed show reduced GR transactivation ability in the liver and maintain transrepressive activity (70), studies have suggested that $\mathrm{GR}^{\mathrm{dim}}$ forms dimers in the nucleus through another dimerization surface of the LBD (80). This suggests that binding to GR half-sites or other DNA motifs may be mediated by GR dimers, where possibly only one part of the dimer binds directly to DNA (Figure 2B). Cistromic analysis of GR and $\mathrm{GR}^{\mathrm{dim}}$ in the liver and in macrophages suggests extensive GR binding to chromatin through GR halfsites, which in many cases colocalizes with lineage-determining TFs driving cell-specific gene transcription $(63,70)$. Accordingly, GC treatment has been suggested to induce pronounced GR redistribution from GR half-sites to canonical GREs leading to reduced transcription of genes controlled by lineage-specific TFs (63). Introducing a mutation that completely disrupts direct GR binding to DNA ( $\left.\mathrm{GR}^{\Delta \mathrm{Zn}}\right)$ leads to a perinatal lethal phenotype similar to knock out of GR, emphasizing an essential function of direct binding to DNA. Interestingly, studies of mouse embryonic fibroblasts isolated from $\mathrm{GR}^{\Delta \mathrm{Zn}}$ mice show that direct GR-DNA interaction is essential for both transcriptional activation and repression by GCs, arguing that tethering is not a dominant mechanism for GR transrepression (81). Thus, genomic action of GR is primarily mediated by multimeric or monomeric actions involving direct interaction with the DNA template.

\section{GR Interaction With Chromatin}

GR binding to DNA is not solely dependent on the DNA sequence of the GRE. As GR binding sites are part of enhancer regions organized in higher order chromatin structures, occupancy of GR to specific regions of the genome is determined by a number of interdependent factors. This includes selective chromatin accessibility, epigenetic modifications of the histones, and the presence of other signal-dependent TFs, lineagedetermining TFs and transcriptional coregulators (56). In the mouse liver, GR binds at least 11,000 distinct regions which are primarily located in intronic and intergenic distal regions $(26,61,63,72,82)$. The vast majority of the GR binding sites are accessible prior to GC stimulation (pre-accessible chromatin) and only some are de novo remodeled following GR recruitment (72). Similar findings are observed for other cell types $(56,83,84)$, demonstrating that selective GR occupancy of chromatin is largely determined by the accessibility of GREs. This pre-programmed chromatin landscape is shaped by cell-specific TFs and interacting coregulators that facilitate an accessible chromatin environment thereby assisting the loading of other TFs to the chromatin (discussed below; Figure 2C) (85). Accordingly, when comparing the liver cistrome across a number of well-described GC-responsive cell types, more than $80 \%$ of GR binding sites are unique to the liver and only $0.5 \%$ of the binding sites in the liver are shared with other cell types (72). This correlates with the findings that GR-occupied enhancers active in one cell type are inaccessible and nucleosomal in another cell type
(73). GR has also been found to facilitate binding of other TFs to enhancers in the liver by establishment of accessible chromatin (72). In fact, binding of GR to genomic regions with different levels of chromatin accessibility has been linked to the type and strength of the GRE motif, with weaker motifs being found at nucleosome-depleted enhancers, compared to more nucleosomal dense sites (73).

\section{Control of Gene Transcription by Recruitment of Coregulators and Chromatin Remodeling}

Upon GR binding to chromatin, the local nucleosome-sparse region expands and the accessibility of the chromatin is further increased trough recruitment of chromatin remodeling complexes such as SWI/SNF and additional TFs (86-88). In addition, GR facilitates recruitment of widely expressed coactivators including histone acetyl transferases CBP, P300, GRIP1, PCAF and SRC-2 and components of the Mediator complex such as MED1 and MED14 (56, 66, 73, 89, 90). Moreover, other important GR coactivators have been identified in the liver, including CRTC2 (91), SIRT1, PGC-1 $\alpha$ (92), ASCOM complex (93) and SETDB2 (94). On the other hand, GR has been found to interact with corepressors including SMRT (95), HDAC1 (96), CtBP (97), SMAD6-HDAC3 (98), CRY1 (99) and recently TAZ (100), although these interactions are not necessarily associated with transcriptional repression. The wide variety of coregulator interactions allows transcriptional finetuning of specific genes in a given cell in a concerted response to cellular signals and circulating GC levels.

Local recruitment of GR and associated coregulators to specific enhancers is translated to a transactivation potential by assembly into higher order enhancer-enhancer and enhancer-promoter condensates (101), facilitating localized increased concentration of the transcriptional machinery (102). Interestingly, interaction between promoters and enhancers occupied by GR is mostly established prior to GC stimulation $(103,104)$, suggesting that GC treatment does not necessarily lead to new chromosomal interactions but rather increases existing interactions between GR-occupied enhancers and GC-regulated target genes (74). Importantly, availability of GCs has been shown to be central for this differential interaction, suggesting that rapid regulation of gene transcription in response to changes in GC levels not only involves dynamic loading of GR and coregulators on the genome but also differential regulation of enhancer-promoter interaction (103).

\section{GR OPERATES IN TRANSCRIPTIONAL NETWORKS TO CONTROL HEPATIC GENE EXPRESSION}

The general GR working model described above illustrates that cell-specific GR actions are orchestrated by auxiliary lineagedetermining and signal-dependent TFs. As any given cell expresses multiple cell-specific TFs that shape the accessible chromatin landscape, it is evident that GR-GC action in a given cell is controlled by signaling pathways regulating the activity 
and expression of these TFs. For example, the liver receives a variety of context-dependent signals controlling specific signaling pathways including circadian cues, insulin, glucagon, growth hormone and free fatty acids, that collectively shape and are shaped by the GC response in hepatocytes. These different signals are integrated in spatial and temporal TF signaling networks that regulate and fine-tune the hepatic transcriptional response. GR interaction with different TFs and the importance of these interactions for transcriptional regulation have been investigated for decades (105). Recently, several key genomewide studies in mouse liver tissue have demonstrated that GR interacts with a large repertoire of TFs and that these interactions are diverse, bidirectional, dynamic and highly context- and cellspecific (Table 1). The interactions between GR and TFs can be classified as direct or indirect. Direct interactions cover proteinprotein interactions or concurrent and co-localized binding to regulatory sites in the chromatin (Figure 3A), impacting coregulator recruitment, and consequently enhancer activity (Figure 3B). Indirect interactions involve TF cascades, where the expression of one TF regulates the expression of another TF (Figure 3C).

\section{Composite TF Interactions and Assisted Loading}

At composite sites, GR binds to GREs and can functionally interact with other TFs bound to a neighboring site in the same regulatory region, co-operatively regulating enhancer activity. These binding sites can be overlapping or closely located on the DNA strand and involve GREs, half GREs and/or nGREs (Figure 3A). Many liver-expressed TFs have been found or suggested to co-occupy GR binding sites (Table 1). ChIP-seq experiments have confirmed the composite binding of CREB1, FOXO1, FOXA, HNF4 $\alpha, \mathrm{HNF} 6, \mathrm{C} / \mathrm{EBP} \alpha, \mathrm{C} / \mathrm{EBP} \beta, \mathrm{PPAR} \alpha, \mathrm{E} 47$, STAT5, and REV-ERB $\alpha$ at several GR-occupied enhancers (26, $61,63,72,82,107,108,110,114)$. In the liver, ChIP-seq data suggests that GR binds GRE half-sites together with lineagedetermining TFs including HNF4 $\alpha, \mathrm{C} / \mathrm{EBP} \beta, \mathrm{HNF} 6$, and FOXA $(63,72)$. In addition, AP-1 and SP1 motifs have been found to be enriched at GR binding sites (122) and the AhR binding site contains a GRE (123), suggesting that these TFs could work together with GR at specific sites to regulate transcription (124). However, further investigations are needed to determine the relevance of AP-1, SP1, and AhR on GR activity in the liver.

Several confirmed composite GR-TF interactions have been found to impact GR activity and hepatic metabolism, including $\mathrm{C} / \mathrm{EBP} \beta$, E47, STAT5, and LXR $\beta$, which are required for GR recruitment to specific sites $(26,72,110,113)$, in accordance with the model for assisted loading. For example, GR and E47 co-occupy many promoters and enhancers, working in synergy to regulate GC-induced metabolic genes. Studies using liverspecific E47 knock-out mice emphasize the importance of E47 in the recruitment of GR, FOXO1, and the mediator complex to composite sites. This cooperation affects glucose, fatty acid and lipid metabolism, which is demonstrated by E47 knock-out mice being protected from GC-induced hyperglycemia, dyslipidemia and hepatic steatosis (110). Another example is the C/EBPfacilitated assisted loading of GR. C/EBP has been found to occupy and prime the majority of GR target sites in the liver, making the chromatin accessible for GR binding. Disruption of C/EBP binding attenuates GR recruitment and GR-induced chromatin remodeling at composite sites (72). The concept of assisted loading is also found reversely, with GR assisting the loading of TFs including C/EBP and CREB1 at a subset of sites (Figure 2C) (72, 107). For example, GR-mediated assisted loading of CREB1 at a subset of CREB1 target enhancers doubles the number of CREB1 bound sites and increases chromatin accessibility, eventually leading to increased hepatic glucose production during fasting (107).

\section{Protein-Protein Interactions: Heterodimerization and Tethering at Chromatin}

As mentioned above, multiple GR isoforms can be generated from the primary transcript and protein processing. Thus, GR $\alpha / \beta$ heterodimers can be formed on chromatin, impacting the activity of occupied enhancers (125-127) (Figure 3A). In fact, GR $\beta$ has been shown to have metabolic relevance in the liver. For example, feeding induces GR $\beta$ expression within $7 \mathrm{~h}$, likely in response to insulin (36). This is supported by observations that hepatic GR $\beta$ expression increases in diet-induced obese mice (128). Overexpression of GR $\beta$ in mouse liver reduces expression of known GR $\alpha$ target genes such as Pck1 and Ppara, associated with disrupted gluconeogenesis and increased hepatic lipid accumulation and inflammation, respectively $(128,129)$. Moreover, the GR $\beta$-mediated increase in lipid accumulation is also seen in L-GRKO mice $(26,130)$, suggesting that GR $\beta$ may function as a negative regulator of GR $\alpha$ in hepatic fatty acid metabolism. Importantly, GR $\beta$ expression in a GR $\alpha$-negative background leads to expression of a specific set of genes not regulated in the presence of GR $\alpha$ (129), suggesting that GR $\alpha$ and GR $\beta$ regulate each other's activities by mechanisms involving accessibility to chromatin, cooperation with TFs and coregulators and indirect regulation of enhancer activity (Figures 3A-C). Likewise, GR has been found to form a heterodimer with the mineralocorticoid receptor (MR) (34) in a number of different tissues and cells, including the hippocampus and mammary cells. Here, the GR-MR complex binds to GREs and regulates gene expression $(131,132)$. Although a GR-MR complex has not, to our knowledge, been shown to be functional in the liver, it has been suggested that GR-MR could regulate hepatic expression of G6Pase (133) (Figure 3B). However, further investigations are needed.

Besides heterodimerization on DNA, GR has been suggested to form other protein-protein interactions on chromatin which tether GR to enhancers independently of its DBD. This includes interaction with COUP-TFII, STAT5, PPAR $\alpha$ and the molecular clock components BMAL1, CLOCK, and REV-ERB $\alpha$, influencing GR activity and hepatic metabolism $(82,106,115,116,119)$. For example, COUP-TFII protein interaction with GR is important for GC-induced promoter activity and hepatic Pck1 gene expression (106). Also, GR is suggested to be recruited to a 
TABLE 1 | Examples of hepatocyte expressed transcription factors interacting with GR on chromatin.

\begin{tabular}{|c|c|c|c|c|c|}
\hline Transcriptio & n factor & Signals regulating TF activity & Interactions with GR & Model & References \\
\hline \multicolumn{6}{|l|}{ Metabolism } \\
\hline $\mathrm{C} / \mathrm{EBP} \alpha$ & $\begin{array}{l}\text { CCAAT enhancer binding protein } \\
\text { alpha }\end{array}$ & & Co-localization & Mouse liver & (72) \\
\hline $\mathrm{C} / \mathrm{EBP} \beta$ & $\begin{array}{l}\text { CCAAT enhancer binding protein } \\
\text { beta }\end{array}$ & & $\begin{array}{l}\text { Co-localization. C/EBP } \beta \text {-mediated } \\
\text { assisted loading of GR }\end{array}$ & Mouse liver & $(63,72)$ \\
\hline $\begin{array}{l}\text { COUP- } \\
\text { TFII }\end{array}$ & $\begin{array}{l}\text { Orphan nuclear receptor chicken } \\
\text { ovalbumin upstream } \\
\text { promoter-transcription factor II }\end{array}$ & $\begin{array}{l}\text { 9-cis-retinoic acid } \\
\text { All-trans-retinoic acid }\end{array}$ & $\begin{array}{l}\text { Protein-protein interaction. } \\
\text { Co-localization on chromatin }\end{array}$ & $\begin{array}{l}\text { H4lIE and } \\
\text { HepG2 }\end{array}$ & (106) \\
\hline CREB1 & $\begin{array}{l}\text { CAMP responsive element } \\
\text { binding protein } 1\end{array}$ & Glucagon & $\begin{array}{l}\text { GR-mediated assisted loading. } \\
\text { Co-localized binding }\end{array}$ & Mouse liver & $(61,107-109)$ \\
\hline E47 & & & $\begin{array}{l}\text { Co-localization on chromatin. E47 is } \\
\text { important for GR recruitment. }\end{array}$ & Mouse liver & (110) \\
\hline FOXA & Forkhead box A1 & & Half-site tethering & Mouse liver & (63) \\
\hline FOXA2 & Forkhead box A2 & & $\begin{array}{l}\text { FOXA2-mediated assisted loading of } \\
\text { GR. Co-localization at site }\end{array}$ & $\begin{array}{l}\text { Mouse liver } \\
\text { and primary } \\
\text { mouse } \\
\text { hepatocytes }\end{array}$ & $(63,109)$ \\
\hline FOXO1 & Forkhead box $\mathrm{O} 1$ & Insulin & $\begin{array}{l}\text { Co-localization on chromatin and } \\
\text { protein-protein interaction }\end{array}$ & $\begin{array}{l}\text { Mouse liver } \\
\text { H4lIE }\end{array}$ & $(61,110,111)$ \\
\hline$L X R \alpha$ & Liver $\mathrm{X}$ receptor alpha & Oxysterols & $\begin{array}{l}\text { Competes with GR for binding at } \\
\text { target sites }\end{array}$ & HepG2 & (112) \\
\hline LXR $\beta$ & Liver $X$ receptor beta & Oxysterols & $\begin{array}{l}\text { Facilitates GR binding to selected } \\
\text { GREs }\end{array}$ & Mouse liver & (113) \\
\hline HNF6 & Hepatocyte nuclear factor 6 & & Half-site tethering & Mouse liver & (63) \\
\hline $\operatorname{PPAR} \alpha$ & $\begin{array}{l}\text { Peroxisome proliferator activated } \\
\text { receptor alpha }\end{array}$ & $\begin{array}{l}\text { Fatty acids, eicosanoids, } \\
\text { phospholipids, polyphenols }\end{array}$ & Co-localization on chromatin & $\begin{array}{l}\text { Primary } \\
\text { mouse } \\
\text { hepatocytes }\end{array}$ & (114) \\
\hline \multicolumn{6}{|c|}{ Circadian clock } \\
\hline BMAL1 & Brain and muscle ARNT-like 1 & Circadian & $\begin{array}{l}\text { Protein-protein interaction. GR is } \\
\text { tethered to BMAL1-CLOCK complex. } \\
\text { Co-localization on chromatin }\end{array}$ & Mouse liver & $(26,115)$ \\
\hline CLOCK & Circadian clock regulator & Circadian & $\begin{array}{l}\text { Protein-protein interaction. GR is } \\
\text { tethered to BMAL1-CLOCK complex. } \\
\text { Co-localization on chromatin }\end{array}$ & Mouse liver & $(26,115)$ \\
\hline CRY1/CRY2 & $\begin{array}{l}\text { Cryptochrome circadian } \\
\text { regulator } 1 / 2\end{array}$ & Circadian & $\begin{array}{l}\text { Co-localization on chromatin through } \\
\text { tethering. Protein-protein interaction }\end{array}$ & $\begin{array}{l}\text { HepG2 cells } \\
\text { Mouse liver }\end{array}$ & $(26,99,116)$ \\
\hline PER1/2 & Period circadian regulator $1 / 2$ & Circadian & Co-localization on chromatin & Mouse liver & (26) \\
\hline $\begin{array}{l}\text { REV- } \\
\text { ERB } \alpha / \beta\end{array}$ & $\begin{array}{l}\text { Nuclear receptor subfamily } 1 \\
\text { group D member } 1 / 2\end{array}$ & Circadian, hem & $\begin{array}{l}\text { Protein-protein interaction. } \\
\text { Co-binding to sites. } \\
\text { REV-ERB } \alpha \text {-mediated assisted loading } \\
\text { of GR }\end{array}$ & Mouse liver & $(26,82)$ \\
\hline $\mathrm{ROR} \alpha / \gamma$ & RAR related orphan receptor $\mathrm{A} / \mathrm{C}$ & Circadian & Co-localization on chromatin & Mouse liver & (26) \\
\hline \multicolumn{6}{|c|}{ Development and growth } \\
\hline $\mathrm{HNF} 1 \alpha$ & $\begin{array}{l}\text { Hepatocyte nuclear factor } 1 \\
\text { alpha }\end{array}$ & & Co-localization at sites & $\begin{array}{l}\text { Mouse liver } \\
\text { PLC/PRF/5 cells }\end{array}$ & $(117,118)$ \\
\hline HNF4a & $\begin{array}{l}\text { Hepatocyte nuclear factor } 4 \\
\text { alpha }\end{array}$ & Linoleic acid & Co-localization at sites & Mouse liver & $(63,117)$ \\
\hline STAT5 & $\begin{array}{l}\text { Signal transducer and activator } \\
\text { of transcription } 5\end{array}$ & Growth hormone. Cytokines & $\begin{array}{l}\text { Protein-protein interaction. } \\
\text { Co-localization at sites. STAT5 tethers } \\
\text { GR to sites. } \\
\text { STAT5 induces GR recruitment } \\
\text { to sites }\end{array}$ & Mouse liver & $(26,119,120)$ \\
\hline \multicolumn{6}{|l|}{ General } \\
\hline HSP90 & Heat shock protein 90 & & $\begin{array}{l}\text { GC-dependent co-localization on } \\
\text { chromatin }\end{array}$ & $\begin{array}{l}\text { Rat hepatoma } \\
\text { HTC cells }\end{array}$ & $(121)$ \\
\hline p23 & Prostaglandin E Synthase 3 & Prostaglandin E Synthase 3 & $\begin{array}{l}\text { GC-dependent co-localization on } \\
\text { chromatin }\end{array}$ & $\begin{array}{l}\text { Rat hepatoma } \\
\text { HTC cells }\end{array}$ & $(121)$ \\
\hline
\end{tabular}




\section{A GR enhancer co-occupancy with TFs}

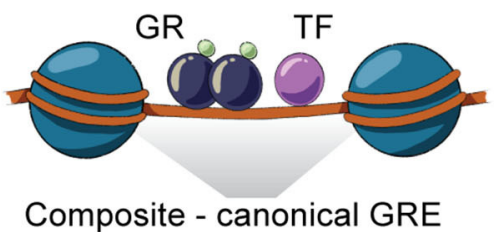

Composite - canonical GRE

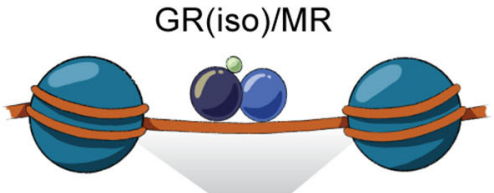

Heterodimerization

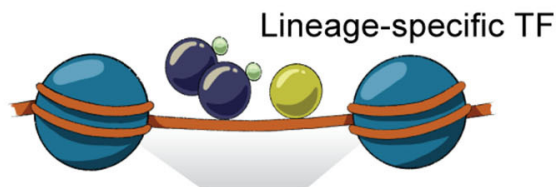

Composite - GRE half-site

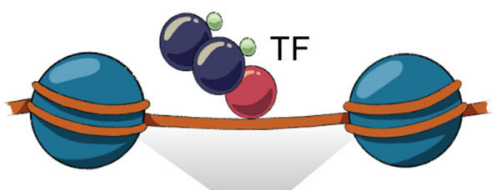

Tethering

B Net enhancer activity by TF co-occupancy

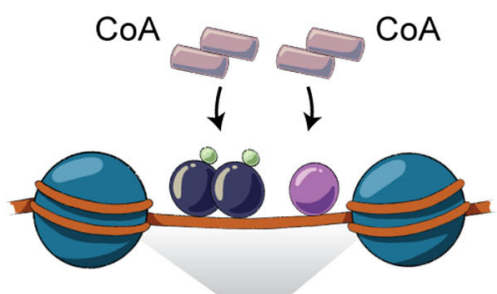

High activity

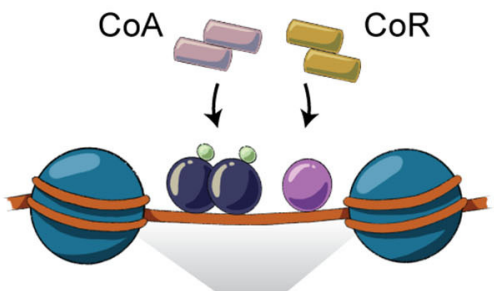

Low activity

C Indirect regulation: TF cascade

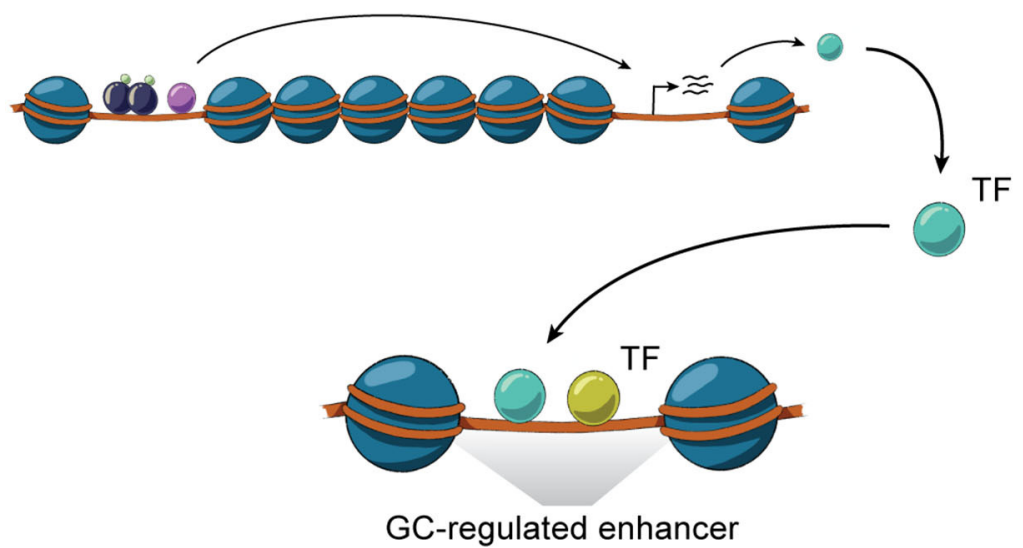

FIGURE 3 | GR interaction with TFs on chromatin. (A) GR and TFs co-occupy enhancers through homodimeric or monomeric GR binding together with TFs at composite sites, by heterodimerization and through tethering. (B) GR- and TF-mediated recruitment of coactivators (CoA) and/or corepressors (CoR) to co-occupied regulatory sites controls the net enhancer activity. (C) Indirect GR-TF interaction involves TF cascades, where the expression of GR regulates the expression of TF or vice versa.

subset of sites via tethering to DNA-bound PPAR $\alpha$ to regulate metabolic genes in the liver including Pdk4 (114). Moreover, GR tethering to the BMAL1-CLOCK complex is suggested to repress hepatic Rev-erba expression (115), demonstrating how GR and the molecular circadian clock interconnect to regulate shared gene programs. 


\section{Controlling Enhancer Activity by Co-occupancy of Multiple TFs}

The transcriptional effect of multiple TF interactions at enhancers can be evaluated by looking at the expression of juxtaposed target genes or at localized histone acetylation and mediator recruitment. In the case of $\mathrm{TF}$ cooperation at individual enhancers, activation of several TFs will result in synergistic effects on enhancer activity and gene expression. In contrast, TFs working independently at the shared enhancer would result in gene expression corresponding to a sum of the contribution from each TF. For example, composite GR$\operatorname{PPAR} \alpha$ sites have been found to synergistically affect the expression of fatty acid oxidation and ketogenic genes while GRCREB1 sites synergistically regulate gluconeogenic genes (107). Likewise, synergistic and additive regulation has been reported for genes controlled by GR and FOXO1 in co-occupancy (61). These cooperative effects likely reflect increased recruitment of coactivators to a given set of enhancers involved in transcription of a specific gene (Figure 3B).

In contrast to the synergistic action of composite GR-TF binding sites to increase enhancer activity, several studies have suggested negative regulation between GR and TFs occupied at a given enhancer. Such negative regulation can be understood as a competition between the TFs for a given DNA sequence. For example, in the liver, LXR $\alpha$ binds GREs together with its heterodimerization partner $\mathrm{RXR} \alpha$, thereby potentially competing with GR for binding to the same sites leading to differential regulation of genes involved in glucose metabolism (112). Another example is the GR isoform competition model, which seeks to explain how dominant negative GR $\beta$ functions as a negative regulator for GR $\alpha$ at some sites. Similarly, GR has been suggested to compete with AP1 at AP1 motifs with embedded GR half-sites (77). However, these competitional models do not agree with the dynamic nature of GR and most other TFs as these factors bind transiently to chromatin with residence times in a matter of seconds $(55,134)$, possibly allowing multiple factors to interact with the same site (135). Thus, GR-TF competition at composite sites is likely not a competition for the same response element. Instead, the negative regulation likely reflects the different coregulators recruited to the response element. Composite binding of different TFs recruiting coregulators of opposite activity or competition between limited amount of avaliable coregulators for binding to the specific TFs would balance the transcriptional response. For example, corepressors and coactivators have been suggested to bind GR in equilibrium, balancing GR activity (136), which has also been suggested for other nuclear receptors in the liver, including the thyroid hormone receptor (137).

\section{Regulating TF Networks by GR}

The direct interaction between GR and other key TFs on chromatin in the liver can take different forms, as described above, to jointly regulate hepatic gene expression. However, indirect GR-TF interactions involving TF cascades are equally important, though more challenging to investigate, with several potential interaction steps (Figure 3C). Important indirect pathways have been studied in the liver. For example, GR binds GREs near core clock genes to induce transcription of Perl, Bmal1, Cry1, Dbp $(138,139)$. This in turn controls a range of circadian-regulated genes. In regards to energy metabolism, GR interacts with several key factors in TF cascades connecting and impacting different signaling pathways. For example, glucagonmediated activation of CREB1 induces the transcription of YY1, which then induces the transcription of GR. This interaction cascade is important in hepatic gluconeogenesis (140). Moreover, GR induces the transcription of Klf9, which has been linked to the downstream induction of PGC1 $\alpha$ expression and of hepatic gluconeogenic genes (141). GR interaction with PGC1 $\alpha$ has furthermore been suggested to regulate mitochondrial oxidative phosphorylation (142). Additionally, GR induces the transcription of PPAR $\alpha$ upon long-term fasting, initiating hepatic fatty acid oxidation and the ketogenic gene program (107).

\section{GR REGULATORY NETWORKS IMPACT MULTIPLE ASPECTS OF HEPATIC METABOLISM}

The emerging studies in complex gene-regulatory networks controlled by GR and controlling GR activity emphasize the importance of the context-dependent action of GCs in tissues like the liver. Accordingly, genetic disruption of GR in the liver impacts a range of metabolic pathways leading to dysregulated glucagon synthesis, lipid metabolism, gluconeogenesis, urea metabolism and bile acid synthesis and uptake (26, 143-146). For example, L-GRKO mice and $\mathrm{GR}^{\mathrm{dim}}$ mice show dysregulated glucose, fatty acid and bile acid metabolism (26, 144, 146). Reduced expression of key gluconeogenic genes including $P c k 1, G 6 P c$, and $P f k f b 3$ in L-GRKO mice is linked to fasting hypoglycemia $(26,144-146)$, and around half of newborn albumin-alpha-fetoprotein-driven L-GRKO mice die within $48 \mathrm{~h}$ after birth, possibly due to hypoglycemia $(120,146)$. L-GRKO mice are more sensitive to insulin than WT littermates and liver glycogen content in L-GRKO mice is reduced (145). These effects of L-GRKO on glucose metabolism could in part be explained by the interaction with TFs such as CREB1, FOXO1, FOXA2, PPAR $\alpha$, E47, STAT5, LXR $\alpha, \operatorname{LXR} \beta$, and circadian regulators $(26,61,82,107,109,110,112-114)$ (Figure 4). Yet, the effects of L-GRKO on glucose metabolism seem to be partially compensated by increased gluconeogenesis in the kidney (145) and by a shifted hormonal balance involving reduced plasma concentration of insulin and increased glucagon levels, compared to WT mice (146).

Hepatic GR disruption also leads to decreased fat mass (145) and lower plasma triglyceride levels $(26,146)$, while free fatty acid plasma levels are similar in fasted and fed L-GRKO mice and WT mice (146). Recently, L-GRKO mice were reported to accumulate triglycerides in the liver and to develop hepatic steatosis (26), although this is controversial (130), but may be explained by the promoter controlling CRE expression. Many TFs have been found to work together with GR to regulate fatty acid and lipid metabolism including STAT5, PPAR $\alpha$, FOXO1, 


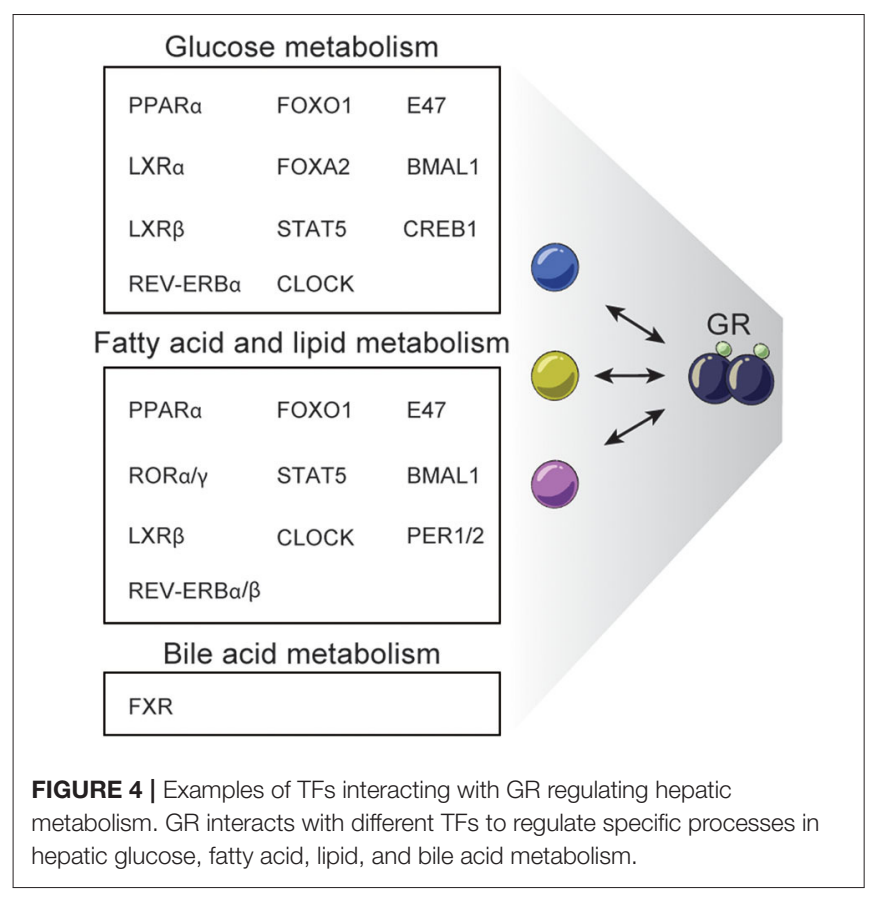

E47, LXR $\beta$, CLOCK, REV-ERB $\alpha / \beta$, CRY, BMAL1, ROR $\alpha / \gamma$, and PER1/2 (26, 82, 110, 111, 113, 114) (Figure 4).

Finally, disruption of hepatic GR function leads to dysregulated systemic bile acid homeostasis. Specifically, mice with hepatic GR knock down by shRNA have a reduced amount of bile acid in the gallbladder, elevated serum bile acid levels, impaired bile acid uptake/transport and are more susceptible to develop gallstones when fed on cholesterol-rich diet. Moreover, these mice do not undergo the normal changes in bile acid levels in the serum, liver and intestines in the fast-refeeding transition (144). GR ${ }^{\mathrm{dim}}$ mice fed a lithogenic diet have elevated fasting serum bile acid levels and decreased gallbladder bile acid volume. These effects have been associated with interaction between GR and FXR, a key TF regulating bile acid metabolism $(97,144)$. GR deficiency reduces the expression of the classical FXR-target gene Shp encoding the SHP repressor, leading to increased expression of the rate-limiting enzymes in bile acid synthesis Cyp7a1 and Cyp8b1 (144). Additionally, dex-induced GR recruits the co-repressor CtBP to block FXR activity at shared sites related to bile acid gene metabolism, e.g. Shp promoter (97) (Figure 4).

\section{EXAMPLES OF KEY HEPATIC GENE REGULATORY NETWORKS CONTROLLED BY GR}

\section{GR Crosstalk With FOXO1}

The daily change from the inactive fasting phase to the active feeding phase requires a major transcriptional reprogramming of the liver. This is particularly relevant at the transition between the unfed and fed states, which takes place around zeitgeber time (ZT) 12 (i.e., 6 p.m.) in nocturnal animals such as mice. The interaction between GR and the insulin-regulated TF FOXO1 is involved in driving this transcriptional transition. Pre-prandial high GC and low insulin levels are associated with GR and FOXO1 binding to chromatin, respectively, and regulation of target genes. In fact, in this fasted state, more than half of all FOXO1 binding sites are co-occupied with GR regulating gene expression. Conversely, the post-prandial increased insulin and reduced GC lead to reduced FOXO1 and GR occupancy, respectively, and reduced transcriptional regulatory activity. Importantly, more than $80 \%$ of feeding-repressed genes in the liver are associated with a nearby enhancer bound by GR, FOXO1 or both (61). One example of a metabolic gene coregulated by GR and FOXO1 in the liver is Angptl4, associated with the regulation of glucose and lipid metabolism. In a fasted state, GR and FOXO1 bind a specific GRE and forkhead box transcription factor response element (FRE), respectively, located in the regulatory region of Angptl4. GCs induce, while insulin abolishes, the occupancy of both factors at the region (111). Besides the direct interaction between GR and FOXO1 at enhancers in the liver, GR has been found to induce the expression of Foxol gene in the liver and in this way indirectly regulate target genes (147). Furthermore, FOXO1 binding has been found at the promoter of GR, suggesting that the indirect interaction is bidirectional (148).

\section{GR Crosstalk With PPAR $\alpha$}

Like GR, PPAR $\alpha$ is important for the hepatic response to fasting. The role of PPAR $\alpha$ in regulating metabolism and inflammation as well as the importance of crosstalk between PPAR $\alpha$ and other TFs, including GR, have been covered in detail in previous reviews $(1,149)$. The GR-PPAR $\alpha$ interactions in the liver include co-localization to chromatin and coregulation of genes involved in lipid and glucose metabolism (150). More specifically, in co-ligand treatment of primary murine hepatocytes, $13 \%$ of GR peaks are co-bound with PPAR $\alpha$ (114). Furthermore, other studies have found that, during fasting, GR and PPAR $\alpha$ have a synergistic effect on genes involved in ketogenesis and fatty acid oxidation; however, the GR-PPAR $\alpha$ interaction has been suggested to be indirect as GR induces the expression of PPAR $\alpha$ and time-course experiments show a gradual effect of GR on PPAR $\alpha$ activity (107).

\section{GR Crosstalk With STAT5}

STAT5 is activated by the growth hormone through the growth hormone receptor-JAK2 signaling pathway and by cytokine signaling. In the liver, STAT5 is known to regulate genes involved in body growth, cell cycle, lipid, bile acid, drug and steroid metabolism (151). The STAT5 and GR signaling pathways are connected as exemplified by the reduced body size in mice with inactivated hepatic GR showing impaired growth hormone signaling (120). Furthermore, the importance of STAT5 and GR signaling is demonstrated in liver-specific STAT5 and STAT5 GR double mutant mice exhibiting hepatic steatosis and, for the double mutant, also hepatic carcinoma (130). The STAT5 and GR crosstalk at multiple levels. STAT5 and GR form proteinprotein interactions in hepatocytes, which have been found to be important for postnatal growth and maturation-related gene expression. Mice expressing a point mutation in the GR DBD 
(GR ${ }^{\text {dim }}$ mice), previously suggested to reduce GR DNA-binding and GR dimerization $(69,79)$, have an unaltered ability to interact with STAT5 (120). These GR ${ }^{\mathrm{dim}}$ mice have normal body size, suggesting that the joint GR-STAT5 regulation of growth genes happens through tethering of GR to the STAT5 bound sites or through half GREs in conjunction with STAT5 binding sites $(119,120)$. However, as mentioned above, more recent studies have found that $\mathrm{GR}^{\mathrm{dim}}$ is able to dimerize and bind DNA (80), suggesting a reassessment of GR and STAT5 interaction type at shared sites.

Recently, it has been shown that high-fat diet feeding of mice leads to reprogramming of the hepatic GR cistrome primarily during the active feeding phase. Many sites with high-fat dietinduced increased GR recruitment are associated with increased STAT5 co-occupancy. These co-occupied sites showed increased enhancer activity and were associated with genes involved in fatty acid, lipid and glucose metabolism. Hepatocyte-specific STAT5 and GR KO mice demonstrated that STAT5 facilitated the recruitment of GR at gained sites, whereas GR had no effect on STAT5 recruitment. It is still unknown whether the increased STAT5 activity in obese mice is a response to altered growth hormone or cytokine signaling or if it originates from nutritional adaptations in the chromatin landscape (26).

\section{GR Crosstalk With Molecular Clock Components}

In the liver, the effect of exogenous GCs on gene regulation is highly dependent on the time of administration. For example, in mice about eight times more genes are differentially regulated by GCs at daytime compared to nighttime. Pathway analysis shows a strong time-dependent regulation of genes in glucose and lipid metabolism (82), which has also been observed in studies looking at endogenous GC effects (26). Hence, timing of GC administration according to the endogenous GC levels has shown positive effects. Administration of GCs at ZT12, as opposed to ZT0, leads to less hepatic lipid accumulation and behavioral changes. This time-differential effect of GC is suggested to be caused by a disrupted circadian regulation of GC-target genes with administration at ZT0, which is supposedly more critical compared to an over-activation of GR at ZT12 (152).

This diurnal oscillation of GC action stems from cooperativity and multiple interactions between GR and the molecular clock components in the liver. For example, GR and central clock components including BMAL1, CLOCK, REV-ERB $\alpha / \beta$, PER1, PER2, CRY1, CRY2, and ROR $\alpha / \gamma$ co-occupy different genes involved in clock function and in metabolism $(26,82,99)$. The cooperativity also involves different physical interactions between GR and clock factors on the chromatin level, regulating the expression of other clock factors and metabolic genes (see Table 1). For example, GR physically interacts with CRY1/2 in a GC-induced manner and, in the post-prandial phase, CRY1/2 represses GR activity on e.g. the expression of Pck1. CRY1/2 deficient mice have constitutively high GC levels and exhibit glucose intolerance, suggesting reduced suppression of HPA axis and increased GR activity in the liver (99).

It has been long known that GC and GC-activated GR influence the expression and circadian phase-shifts of several clock factors, including Per1, Dbp and Cry1 (23, 30, 139). In fact,
GR is recruited to the promoters and enhancers of all central clock genes, suggesting a gene regulatory function of GR (26). Reversely, molecular clock elements also affect GR function, as exemplified by the previously mentioned binding of REV-ERB $\alpha$ to HSP90 (53) and the acetylation of GR by CLOCK (46), both leading to suppression of GR action.

The interaction between GR and members of the molecular clock and its influence on hepatic metabolism can be further exemplified focusing on a single molecular factor. REV-ERB $\alpha$ is one of the key transcriptional repressors in the molecular transcriptional clock, contributing to the characteristic circadian expression in many tissues, including the brain and metabolic tissues like the liver, muscle, pancreas and adipose tissue. In the liver, $R E V-E R B \alpha$ is involved in the daily regulation of glucose and lipid metabolism (153). REV-ERB $\alpha$ represses clock genes by binding to RevDR2/RORE DNA elements and recruiting the corepressor complex NCoR-HDAC3. On the other hand, $\mathrm{REV}-\mathrm{ERB} \alpha$ regulates many metabolic genes by tethering to celltype specific TFs. Hepatic REV-ERB $\alpha$ tethers to e.g., HNF6 and recruits HDAC3 for active repression of lipogenic genes (154, 155). GR has been found to interact with REV-ERB $\alpha$ on different levels. REV-ERB $\alpha$ interacts physically with GR and, together with HNF4 $\alpha$ and HNF6, binds regulatory regions controlling gene expression in mouse liver. $\mathrm{REV}-\mathrm{ERB} \alpha$ was found to be important for efficient GR recruitment to chromatin during the day, presumably by maintaining histone acetylation at binding sites (82). Moreover, indirect interactions between GR and REV$\mathrm{ERB} \alpha$ have also been observed. REV-ERB $\alpha$ inhibits GR protein expression and nuclear localization (53), and GR inhibits REV$\mathrm{ERB} \alpha \mathrm{RNA}$ expression (156) by forming a complex with CLOCK and BMAL1, where GR may be tethered to the regulatory site of the REV-ERB $\alpha$ gene (115).

\section{PERSPECTIVES IN DISEASE AND CLINICAL USE OF GCs}

Glucocorticoids have immunosuppressant and antiinflammatory properties, making them an effective treatment for allergies, inflammatory and autoimmune diseases. The anti-inflammatory effects mediated by GR are conducted by the immune cells, with the macrophages having a particularly important role in the repression of inflammatory genes [reviewed in (157)]. However, by administering GCs systemically, there is a risk of eliciting undesirable side effects on other tissues and cellular processes, such as hepatic metabolism, which is highly impacted by GR regulation. In this review, we described the multiple layers of regulation of GR function, from the control of hormonal availability to the modulation of GR expression at both mRNA and protein levels, as well as PTMs and interactions with different proteins and TFs affecting the transcriptional activity of GR. In depth knowledge of the multifaced control of GR activity provides a unique opportunity to tailor GC treatment and prevent metabolic-related side effects.

One strategy could involve administration of different GR ligands affecting interacting coregulators to modulate transcriptional regulation by GR (8). Another strategy could be to selectively activate or inhibit specific and relevant GR-mediated 
regulatory pathways, where treatments involving a combination of different TF ligands could have potential. For example, co-administration of GC and LXR agonists attenuates the transcriptional activity of GR on a subset of genes in glucose and lipid metabolism, suggesting co-treatment with LXR $\beta$ agonists might reduce metabolic side effects in patients with autoimmune or inflammatory diseases (112). However, the function of LXRs on GR target sites is debated (113), and the mechanisms behind the positive and negative effects of LXRs on GR should be elucidated. Also, the antagonistic effect of activated PPAR $\alpha$ on GR-mediated transcription of metabolic genes to circumvent GC side effects seems promising (150), with potentials and challenges recently discussed in another review (1). Additionally, the natural ultradian GC release and subsequent dynamic activation of GR contrasts with the constant exposure to GCs during pharmacological therapies. The development of new synthetic GCs and pulsatory administration strategies could potentially minimize side effects by mimicking physiology $(58,59,103)$. Finally, pharmacological chronotherapy involving GCs seems promising in several inflammatory disorders, with outcomes improving when GC administration is consistently timed (4). This timed GC-administration has been shown to be beneficial in, for example, patients with rheumatoid arthritis (158).

\section{CONCLUDING REMARKS}

The multifaceted regulation of GC action and GR activity discussed in this review highlights the complexity of transcriptional regulation by ligand-dependent TFs. The cooperation with signal-dependent and lineage-specific TFs

\section{REFERENCES}

1. Vandewalle J, Luypaert A, de Bosscher K, Libert C. Therapeutic mechanisms of glucocorticoids. Trends Endocrinol Metab. (2018) 29:4254. doi: 10.1016/j.tem.2017.10.010

2. Rose AJ, Vegiopoulos A, Herzig S. Role of glucocorticoids and the glucocorticoid receptor in metabolism: insights from genetic manipulations. J Steroid Biochem Mol Biol. (2010) 122:10-20. doi: 10.1016/j.jsbmb.2010.02.010

3. Challet E. Keeping circadian time with hormones. Diabetes Obes Metab. (2015) 17:76-83. doi: 10.1111/dom.12516

4. Spencer RL, Chun LE, Hartsock MJ, Woodruff ER. Glucocorticoid hormones are both a major circadian signal and major stress signal: how this shared signal contributes to a dynamic relationship between the circadian and stress systems. Front Neuroendocrinol. (2018) 49:5271. doi: 10.1016/j.yfrne.2017.12.005

5. Ishida A, Mutoh $\mathrm{T}$, Ueyama $\mathrm{T}$, Bando $\mathrm{H}$, Masubuchi $\mathrm{S}$, Nakahara D, et al. Light activates the adrenal gland: timing of gene expression and glucocorticoid release. Cell Metab. (2005) 2:297-307. doi: 10.1016/j.cmet.2005.09.009

6. Bertram R, Satin LS, Sherman AS. Closing in on the mechanisms of pulsatile insulin secretion. Diabetes. (2018) 67:351-9. doi: 10.2337/dbi17-0004

7. Giustina A, Veldhuis JD. Pathophysiology of the neuroregulation of growth hormone secretion in experimental animals and the human. Endocr Rev. (1998) 19:717-97. doi: 10.1210/er.19.6.717

8. Biddie SC, Conway-Campbell BL, Lightman SL. Dynamic regulation of glucocorticoid signalling in health and disease. Rheumatology. (2012) 51:403-12. doi: 10.1093/rheumatology/ker215 makes GC-dependent gene regulation very responsive to environmental cues and is thus essential to understand for future optimized usage of GCs in the clinic. Specifically, a deeper understanding of the regulatory mechanisms underlying GR action would be fundamental for future development of safer and more effective therapies for disorders where GC secretion and signaling is involved. The recent genomics studies into the GR interactome show promise in the elucidation of the complex GR-TF networks and could contribute to a shift toward future tailored pharmacological strategies including spatio-temporal drug delivery and personalized medicine.

\section{AUTHOR CONTRIBUTIONS}

SP and CC wrote the manuscript with supervision from LG. All authors contributed to the article and approved the submitted version.

\section{FUNDING}

This work was supported by funding from the SDU2020 initiative, the Novo Nordisk Foundation and Independent Research Fund Denmark (Sapere Aude: DFF-Starting Grant).

\section{ACKNOWLEDGMENTS}

Illustration of Figure 1 and elements used for Figures 2, 3 was created by scientific illustrator CC. We would like to acknowledge Claes S. Wassmann for critical review and comments.

9. Lightman SL, Birnie MT, Conway-Campbell BL. Dynamics of ACTH and cortisol secretion and implications for disease. Endocr Rev. (2020) 41:47090. doi: 10.1210/endrev/bnaa002

10. Perogamvros I, Kayahara M, Trainer PJ, Ray DW. Serum regulates cortisol bioactivity by corticosteroid-binding globulin-dependent and independent mechanisms, as revealed by combined bioassay and physicochemical assay approaches. Clin Endocrinol. (2011) 75:31-8. doi: 10.1111/j.1365-2265.2011.04003.x

11. Desantis LM, Delehanty B, Weir JT, Boonstra R. Mediating free glucocorticoid levels in the blood of vertebrates: are corticosteroid-binding proteins always necessary? Funct Ecol. (2013) 27:107-19. doi: 10.1111/1365-2435.12038

12. Breuner CW, Orchinik M. Plasma binding proteins as mediators of corticosteroid action in vertebrates. J Endocrinol. (2002) 175:99112. doi: $10.1677 /$ joe. 0.1750099

13. Richard EM, Helbling JC, Tridon C, Desmedt A, Minni AM, Cador M, et al. Plasma transcortin influences endocrine and behavioral stress responses in mice. Endocrinology. (2010) 151:649-59. doi: 10.1210/en.2009-0862

14. Basu R, Singh RJ, Basu A, Chittilapilly EG, Johnson CM, Toffolo G, et al. Splanchnic cortisol production occurs in humans. Diabetes. (2004) 53:2051. doi: 10.2337/diabetes.53.8.2051

15. Stimson RH, Andersson J, Andrew R, Redhead DN, Karpe F, Hayes PC, et al. Cortisol release from adipose tissue by $11 \beta$-hydroxysteroid dehydrogenase type 1 in humans. Diabetes. (2009) 58:46-53. doi: 10.2337/db08-0969

16. Maser E, Völker B, Friebertshäuser J. 11 $\beta$-hydroxysteroid dehydrogenase type 1 from human liver: dimerization and enzyme cooperativity support its postulated role as glucocorticoid reductase. Biochemistry. (2002) 41:245965. doi: 10.1021/bi015803t 
17. Andrew R, Westerbacka J, Wahren J, Yki-Järvinen H, Walker BR. The contribution of visceral adipose tissue to splanchnic cortisol production in healthy humans. Diabetes. (2005) 54:1364. doi: 10.2337/diabetes.54.5. 1364

18. Dammann C, Stapelfeld C, Maser E. Expression and activity of the cortisol-activating enzyme 11 beta-hydroxysteroid dehydrogenase type 1 is tissue and species-specific. Chem Biol Interact. (2019) 303:5761. doi: 10.1016/j.cbi.2019.02.018

19. Kotelevtsev Y, Holmes MC, Burchell A, Houston PM, Schmoll D, Jamieson $\mathrm{P}$, et al. 11 beta-hydroxysteroid dehydrogenase type 1 knockout mice show attenuated glucocorticoid-inducible responses and resist hyperglycemia on obesity or stress. Proc Natl Acad Sci USA. (1997) 94:149249. doi: 10.1073/pnas.94.26.14924

20. Moore RY, Eichler VB. Loss of a circadian adrenal corticosterone rhythm following suprachiasmatic lesions in the rat. Brain Res. (1972) 42:2016. doi: 10.1016/0006-8993(72)90054-6

21. Focke $\mathrm{CMB}$, Iremonger KJ. Rhythmicity matters: circadian and ultradian patterns of HPA axis activity. Mol Cell Endocrinol. (2020) 501:110652. doi: 10.1016/j.mce.2019.110652

22. Neumann AM, Schmidt CX, Brockmann RM, Oster H. Circadian regulation of endocrine systems. Auton Neurosci Basic Clin. (2019) 216:18. doi: 10.1016/j.autneu.2018.10.001

23. Balsalobre A, Brown SA, Marcacci L, Tronche F, Kellendonk C, Reichardt $\mathrm{HM}$, et al. Resetting of circadian time peripheral tissues by glucocorticoid signaling. Science. (2000) 289:2344-7. doi: 10.1126/science.289. 5488.2344

24. Damiola F, Le Minh N, Preitner N, Kornmann B, Fleury-Olela F, Schibler U. Restricted feeding uncouples circadian oscillators in peripheral tissues from the central pacemaker in the suprachiasmatic nucleus. Genes Dev. (2000) 14:2950-61. doi: 10.1101/gad.183500

25. Stokkan KA, Yamazaki S, Tei H, Sakaki Y, Menaker M. Entrainment of the circadian clock in the liver by feeding. Science. (2001) 291:4903. doi: 10.1126/science.291.5503.490

26. Quagliarini F, Mir AA, Balazs K, Wierer M, Dyar KA, Jouffe $\mathrm{C}$, et al. Cistromic reprogramming of the diurnal glucocorticoid hormone response by high-fat diet. Mol Cell. (2019) 76:53145.e5. doi: 10.1016/j.molcel.2019.10.007

27. Silver R, Balsam P. Oscillators entrained by food and the emergence of anticipatory timing behaviors. Sleep Biol Rhythms. (2010) 8:12036. doi: 10.1111/j.1479-8425.2010.00438.x

28. Sheward WJ, Maywood ES, French KL, Horn JM, Hastings MH, Seckl JR, et al. Entrainment to feeding but not to light: circadian phenotype of VPAC(2) receptor-null mice. J Neurosci. (2007) 27:43518. doi: 10.1523/JNEUROSCI.4843-06.2007

29. Sasaki H, Hattori Y, Ikeda Y, Kamagata M, Iwami S, Yasuda S, et al. Phase shifts in circadian peripheral clocks caused by exercise are dependent on the feeding schedule in PER2::LUC mice. Chronobiol Int. (2016) 33:84962. doi: 10.3109/07420528.2016.1171775

30. Le Minh N, Damiola F, Tronche F, Schutz G, Schibler U. Glucocorticoid hormones inhibit food-induced phase-shifting of peripheral circadian oscillators. Embo J. (2001) 20:7128-36. doi: 10.1093/emboj/20.24.7128

31. Tahara Y, Shibata S. Entrainment of the mouse circadian clock: effects of stress, exercise, and nutrition. Free Radic Biol Med. (2018) 119:12938. doi: 10.1016/j.freeradbiomed.2017.12.026

32. Carlstedt-Duke J, Strömstedt PE, Wrange O, Bergman T, Gustafsson JA, Jörnvall H. Domain structure of the glucocorticoid receptor protein. Proc Natl Acad Sci USA. (1987) 84:4437-40. doi: 10.1073/pnas.84.13.4437

33. Hollenberg SM, Evans RM. Multiple and cooperative trans-activation domains of the human glucocorticoid receptor. Cell. (1988) 55:899906. doi: 10.1016/0092-8674(88)90145-6

34. Bledsoe RK, Montana VG, Stanley TB, Delves CJ, Apolito CJ, McKee DD, et al. Crystal structure of the glucocorticoid receptor ligand binding domain reveals a novel mode of receptor dimerization and coactivator recognition. Cell. (2002) 110:93-105. doi: 10.1016/S0092-8674(02)00817-6

35. Oakley RH, Cidlowski JA. The biology of the glucocorticoid receptor: new signaling mechanisms in health and disease. J Allergy Clin Immunol. (2013) 132:1033-44. doi: 10.1016/j.jaci.2013.09.007
36. Hinds TD, Jr., Ramakrishnan S, Cash HA, Stechschulte LA, Heinrich G, Najjar SM, et al. Discovery of glucocorticoid receptor-beta in mice with a role in metabolism. Mol Endocrinol. (2010) 24:171527. doi: 10.1210/me.2009-0411

37. Vandevyver S, Dejager L, Libert C. Comprehensive overview of the structure and regulation of the glucocorticoid receptor. Endocr Rev. (2014) 35:67193. doi: 10.1210/er.2014-1010

38. DuBois DC, Sukumaran S, Jusko WJ, Almon RR. Evidence for a glucocorticoid receptor beta splice variant in the rat and its physiological regulation in liver. Steroids. (2013) 78:312-20. doi: 10.1016/ j.steroids.2012.11.014

39. Kino T, Hurt DE, Ichijo T, Nader N, Chrousos GP. Noncoding RNA Gas5 is a growth arrest- and starvation-associated repressor of the glucocorticoid receptor. Sci Signal. (2010) 3:ra8. doi: 10.1126/scisignal.2000568

40. Galliher-Beckley AJ, Williams JG, Collins JB, Cidlowski JA. Glycogen synthase kinase 3 beta-mediated serine phosphorylation of the human glucocorticoid receptor redirects gene expression profiles. Mol Cell Biol. (2008) 28:7309-22. doi: 10.1128/MCB.00808-08

41. Orti E, Mendel DB, Smith LI, Munck A. Agonist-dependent phosphorylation and nuclear dephosphorylation of glucocorticoid receptors in intact-cells. J Biol Chem. (1989) 264:9728-31.

42. Orti E, Mendel DB, Smith LI, Bodwell JE, Munck A. A dynamic-model of glucocorticoid receptor phosphorylation and cycling in intact-cells. J Steroid Biochem Mol Biol. (1989) 34:85-96. doi: 10.1016/0022-4731(89)90069-1

43. Webster JC, Jewell CM, Bodwell JE, Munck A, Sar M, Cidlowski JA. Mouse glucocorticoid receptor phosphorylation status influences multiple functions of the receptor protein. J Biol Chem. (1997) 272:928793. doi: 10.1074/jbc.272.14.9287

44. Galliher-Beckley AJ, Cidlowski JA. Emerging roles of glucocorticoid receptor phosphorylation in modulating glucocorticoid hormone action in health and disease. IUBMB Life. (2009) 61:979-86. doi: 10.1002/iub.245

45. Avenant C, Ronacher K, Stubsrud E, Louw A, Hapgood JP. Role of ligand-dependent GR phosphorylation and half-life in determination of ligand-specific transcriptional activity. Mol Cell Endocrinol. (2010) 327:7288. doi: 10.1016/j.mce.2010.06.007

46. Nader N, Chrousos GP, Kino T. Circadian rhythm transcription factor CLOCK regulates the transcriptional activity of the glucocorticoid receptor by acetylating its hinge region lysine cluster: potential physiological implications. Faseb J. (2009) 23:1572-83. doi: 10.1096/fj.08117697

47. Wilkinson L, Verhoog N, Louw A. Novel role for receptor dimerization in post-translational processing and turnover of the GR alpha. Sci Rep. (2018) 8:17. doi: 10.1038/s41598-018-32440-Z

48. Wallace AD, Cidlowski JA. Proteasome-mediated glucocorticoid receptor degradation restricts transcriptional signaling by glucocorticoids. J Biol Chem. (2001) 276:42714-21. doi: 10.1074/jbc.M106033200

49. Wallace AD, Cao Y, Chandramouleeswaran S, Cidlowski JA. Lysine 419 targets human glucocorticoid receptor for proteasomal degradation. Steroids. (2010) 75:1016-23. doi: 10.1016/j.steroids.2010.06.015

50. Vandevyver S, Dejager L, Libert C. On the trail of the glucocorticoid receptor: into the nucleus and back. Traffic. (2012) 13:364-74. doi: 10.1111/j.1600-0854.2011.01288.x

51. Timmermans S, Souffriau J, Libert C. A general introduction to glucocorticoid biology. Front Immunol. (2019) 10:1545. doi: 10.3389/ fimmu.2019.01545

52. Warrier M, Hinds TD, Ledford KJ, Cash HA, Patel PR, Bowman TA, et al. Susceptibility to diet-induced hepatic steatosis and glucocorticoid resistance in FK506-Binding protein 52-deficient mice. Endocrinology. (2010) 151:3225-36. doi: 10.1210/en.2009-1158

53. Okabe T, Chavan R, Fonseca Costa SS, Brenna A, Ripperger JA, Albrecht U. REV-ERBalpha influences the stability and nuclear localization of the glucocorticoid receptor. J Cell Sci. (2016) 129:4143-54. doi: 10.1242/jcs.190959

54. Winkler R, Benz V, Clemenz M, Bloch M, Foryst-Ludwig A, Wardat $\mathrm{S}$, et al. Histone deacetylase 6 (HDAC6) is an essential modifier of glucocorticoid-induced hepatic gluconeogenesis. Diabetes. (2012) 61:51323. doi: $10.2337 / \mathrm{db} 11-0313$ 
55. Keizer VIP, Coppola S, Houtsmuller AB, Geverts B, van Royen ME, Schmidt $\mathrm{T}$, et al. Repetitive switching between DNA-binding modes enables target finding by the glucocorticoid receptor. J Cell Sci. (2019) 132:jcs.217455. doi: 10.1242/jcs.217455

56. McDowell IC, Barrera A, D'Ippolito AM, Vockley CM, Hong LK, Leichter SM, et al. Glucocorticoid receptor recruits to enhancers and drives activation by motif-directed binding. Genome Res. (2018) 28:127284. doi: 10.1101/gr.233346.117

57. Paakinaho V, Presman DM, Ball DA, Johnson TA, Schiltz RL, Levitt P, et al. Single-molecule analysis of steroid receptor and cofactor action in living cells. Nat Commun. (2017) 8:15896. doi: 10.1038/ncomms15896

58. Stavreva DA, Garcia DA, Fettweis G, Gudla PR, Zaki GF, Soni V, et al. Transcriptional bursting and co-bursting regulation by steroid hormone release pattern and transcription factor mobility. Mol Cell. (2019) 75:116177.e11. doi: 10.1016/j.molcel.2019.06.042

59. Stavreva DA, Wiench M, John S, Conway-Campbell BL, McKenna MA, Pooley JR, et al. Ultradian hormone stimulation induces glucocorticoid receptor-mediated pulses of gene transcription. Nat Cell Biol. (2009) 11:1093-102. doi: 10.1038/ncb1922

60. Bahar Halpern K, Tanami S, Landen S, Chapal M, Szlak L, Hutzler A, et al. Bursty gene expression in the intact mammalian liver. Mol Cell. (2015) 58:147-56. doi: 10.1016/j.molcel.2015.01.027

61. Kalvisa A, Siersbaek MS, Praestholm SM, Christensen LJL, Nielsen R, Stohr O, et al. Insulin signaling and reduced glucocorticoid receptor activity attenuate postprandial gene expression in liver. PLos Biol. (2018) 16:e2006249. doi: 10.1371/journal.pbio.2006249

62. Cassuto H, Kochan K, Chakravarty K, Cohen H, Blum B, Olswang Y, et al. Glucocorticoids regulate transcription of the gene for phosphoenolpyruvate carboxykinase in the liver via an extended glucocorticoid regulatory unit. $J$ Biol Chem. (2005) 280:33873-84. doi: 10.1074/jbc.M504119200

63. Lim HW, Uhlenhaut NH, Rauch A, Weiner J, Hubner S, Hubner N, et al. Genomic redistribution of GR monomers and dimers mediates transcriptional response to exogenous glucocorticoid in vivo. Genome Res. (2015) 25:836-44. doi: 10.1101/gr.188581.114

64. Presman DM, Ganguly S, Schiltz RL, Johnson TA, Karpova TS, Hager GL. DNA binding triggers tetramerization of the glucocorticoid receptor in live cells. Proc Natl Acad Sci USA. (2016) 113:8236-41. doi: 10.1073/pnas.1606774113

65. Schiller BJ, Chodankar R, Watson LC, Stallcup MR, Yamamoto KR. Glucocorticoid receptor binds half sites as a monomer and regulates specific target genes. Genome Biol. (2014) 15:418. doi: 10.1186/s13059-014-0418-y

66. Weikum ER, Knuesel MT, Ortlund EA, Yamamoto KR. Glucocorticoid receptor control of transcription: precision and plasticity via allostery. Nat Rev Mol Cell Biol. (2017) 18:159-74. doi: 10.1038/nrm.2016.152

67. Surjit M, Ganti KP, Mukherji A, Ye T, Hua G, Metzger D, et al. Widespread negative response elements mediate direct repression by agonist-liganded glucocorticoid receptor. Cell. (2011) 145:224-41. doi: 10.1016/j.cell.2011.03.027

68. Hudson WH, Kossmann BR, de Vera IM, Chuo SW, Weikum ER, Eick GN, et al. Distal substitutions drive divergent DNA specificity among paralogous transcription factors through subdivision of conformational space. Proc Natl Acad Sci USA. (2016) 113:326-31. doi: 10.1073/pnas.1518960113

69. Reichardt HM, Kaestner KH, Tuckermann J, Kretz O, Wessely O, Bock R, et al. DNA binding of the glucocorticoid receptor is not essential for survival. Cell. (1998) 93:531-41. doi: 10.1016/S0092-8674(00)81183-6

70. Frijters R, Fleuren W, Toonen EJ, Tuckermann JP, Reichardt HM, van der Maaden $\mathrm{H}$, et al. Prednisolone-induced differential gene expression in mouse liver carrying wild type or a dimerization-defective glucocorticoid receptor. BMC Genomics. (2010) 11:359. doi: 10.1186/1471-2164-11-359

71. Petta I, Dejager L, Ballegeer M, Lievens S, Tavernier J, De Bosscher $\mathrm{K}$, et al. The interactome of the glucocorticoid receptor and its influence on the actions of glucocorticoids in combatting inflammatory and infectious diseases. Microbiol Mol Biol Rev. (2016) 80:495-522. doi: 10.1128/MMBR.00064-15

72. Grøntved L, John S, Baek S, Liu Y, Buckley JR, Vinson C, et al. C/EBP maintains chromatin accessibility in liver and facilitates glucocorticoid receptor recruitment to steroid response elements. Embo J. (2013) 32:156883. doi: $10.1038 /$ emboj.2013.106
73. Johnson TA, Chereji RV, Stavreva DA, Morris SA, Hager GL, Clark DJ. Conventional and pioneer modes of glucocorticoid receptor interaction with enhancer chromatin in vivo. Nucleic Acids Res. (2018) 46:20314. doi: 10.1093/nar/gkx1044

74. D'Ippolito AM, McDowell IC, Barrera A, Hong LK, Leichter SM, Bartelt LC, et al. Pre-established chromatin interactions mediate the genomic response to glucocorticoids. Cell Syst. (2018) 7:146-60.e7. doi: 10.1016/j.cels.2018.06.007

75. Desmet SJ, de Bosscher K. Glucocorticoid receptors: finding the middle ground. J Clin Invest. (2017) 127:1136-45. doi: 10.1172/JCI88886

76. Hudson WH, Youn C, Ortlund EA. The structural basis of direct glucocorticoid-mediated transrepression. Nat Struct Mol Biol. (2013) 20:538. doi: $10.1038 / \mathrm{nsmb} .2456$

77. Weikum ER, de Vera IMS, Nwachukwu JC, Hudson WH, Nettles KW, Kojetin DJ, et al. Tethering not required: the glucocorticoid receptor binds directly to activator protein-1 recognition motifs to repress inflammatory genes. Nucleic Acids Res. (2017) 45:8596-608. doi: 10.1093/nar/gkx509

78. Johnson GD, Barrera A, McDowell IC, D'Ippolito AM, Majoros WH, Vockley CM, et al. Human genome-wide measurement of drug-responsive regulatory activity. Nat Commun. (2018) 9:5317. doi: 10.1038/s41467-018-07607-x

79. Heck S, Kullmann M, Gast A, Ponta H, Rahmsdorf HJ, Herrlich P, et al. A distinct modulating domain in glucocorticoid receptor monomers in the repression of activity of the transcription factor AP-1. Embo J. (1994) 13:4087-95. doi: 10.1002/j.1460-2075.1994.tb06726.x

80. Presman DM, Ogara MF, Stortz M, Alvarez LD, Pooley JR, Schiltz $\mathrm{RL}$, et al. Live cell imaging unveils multiple domain requirements for in vivo dimerization of the glucocorticoid receptor. PLoS Biol. (2014) 12:e1001813. doi: 10.1371/journal.pbio.1001813

81. Escoter-Torres L, Greulich F, Quagliarini F, Wierer M, Uhlenhaut NH. Antiinflammatory functions of the glucocorticoid receptor require DNA binding. Nucleic Acids Res. (2020) 48:8393-407. doi: 10.1093/nar/gkaa565

82. Caratti G, Iqbal M, Hunter L, Kim D, Wang P, Vonslow RM, et al. REVERBa couples the circadian clock to hepatic glucocorticoid action. J Clin Invest. (2018) 128:4454-71. doi: 10.1172/JCI96138

83. John S, Sabo PJ, Thurman RE, Sung MH, Biddie SC, Johnson TA, et al. Chromatin accessibility pre-determines glucocorticoid receptor binding patterns. Nat Genet. (2011) 43:264-8. doi: 10.1038/ng.759

84. Love MI, Huska MR, Jurk M, Schopflin R, Starick SR, Schwahn K, et al. Role of the chromatin landscape and sequence in determining cell type-specific genomic glucocorticoid receptor binding and gene regulation. Nucleic Acids Res. (2017) 45:1805-19. doi: 10.1093/nar/gkw1163

85. Voss TC, Hager GL. Dynamic regulation of transcriptional states by chromatin and transcription factors. Nat Rev Genet. (2014) 15:6981. doi: $10.1038 / \mathrm{nrg} 3623$

86. Burd CJ, Ward JM, Crusselle-Davis VJ, Kissling GE, Phadke D, Shah RR, et al. Analysis of chromatin dynamics during glucocorticoid receptor activation. Mol Cell Biol. (2012) 32:1805-17. doi: 10.1128/MCB.06206-11

87. Nagaich AK, Walker DA, Wolford R, Hager GL. Rapid periodic binding and displacement of the glucocorticoid receptor during chromatin remodeling. Mol Cell. (2004) 14:163-74. doi: 10.1016/S1097-2765(04)00178-9

88. Muratcioglu S, Presman DM, Pooley JR, Grontved L, Hager GL, Nussinov $\mathrm{R}$, et al. Structural modeling of GR interactions with the SWI/SNF chromatin remodeling complex and C/EBP. Biophys J. (2015) 109:122739. doi: 10.1016/j.bpj.2015.06.044

89. Bartlett AA, Lapp HE, Hunter RG. Epigenetic mechanisms of the glucocorticoid receptor. Trends Endocrinol Metab. (2019) 30:807-18. doi: 10.1016/j.tem.2019.07.003

90. Chen W, Roeder RG. The mediator subunit MED1/TRAP220 is required for optimal glucocorticoid receptor-mediated transcription activation. Nucleic Acids Res. (2007) 35:6161-9. doi: 10.1093/nar/gkm661

91. Hill MJ, Suzuki S, Segars JH, Kino T. CRTC2 is a coactivator of gr and couples gr and creb in the regulation of hepatic gluconeogenesis. Mol Endocrinol. (2016) 30:104-17. doi: 10.1210/me.2015-1237

92. Suzuki S, Iben JR, Coon SL, Kino T. SIRT1 is a transcriptional enhancer of the glucocorticoid receptor acting independently to its deacetylase activity. Mol Cell Endocrinol. (2018) 461:178-87. doi: 10.1016/j.mce.2017. 09.012 
93. Ananthanarayanan M, Li Y, Surapureddi S, Balasubramaniyan N, Ahn J, Goldstein JA, et al. Histone H3K4 trimethylation by MLL3 as part of ASCOM complex is critical for NR activation of bile acid transporter genes and is downregulated in cholestasis. Am J Physiol Gastrointest Liver Physiol. (2011) 300:G771-81. doi: 10.1152/ajpgi.00499.2010

94. Roqueta-Rivera M, Esquejo RM, Phelan PE, Sandor K, Daniel B, Foufelle F, et al. SETDB2 links glucocorticoid to lipid metabolism through insig2a regulation. Cell Metab. (2016) 24:474-84. doi: 10.1016/j.cmet.2016. 07.025

95. Ki SH, Cho IJ, Choi DW, Kim SG. Glucocorticoid receptor (GR)-associated SMRT binding to C/EBPbeta TAD and Nrf2 Neh4/5: role of SMRT recruited to GR in GSTA2 gene repression. Mol Cell Biol. (2005) 25:415065. doi: 10.1128/MCB.25.10.4150-4165.2005

96. Qiu Y, Zhao Y, Becker M, John S, Parekh BS, Huang S, et al. HDAC1 acetylation is linked to progressive modulation of steroid receptor-induced gene transcription. Mol Cell. (2006) 22:669-79. doi: 10.1016/j.molcel.2006.04.019

97. Lu Y, Zhang Z, Xiong X, Wang X, Li J, Shi G, et al. Glucocorticoids promote hepatic cholestasis in mice by inhibiting the transcriptional activity of the farnesoid X receptor. Gastroenterology. (2012) 143:163040.e8. doi: 10.1053/j.gastro.2012.08.029

98. Ichijo T, Voutetakis A, Cotrim AP, Bhattachryya N, Fujii M, Chrousos GP, et al. The Smad6-histone deacetylase 3 complex silences the transcriptional activity of the glucocorticoid receptor: potential clinical implications. J Biol Chem. (2005) 280:42067-77. doi: 10.1074/jbc.M509338200

99. Lamia KA, Papp SJ, Yu RT, Barish GD, Uhlenhaut NH, Jonker JW, et al. Cryptochromes mediate rhythmic repression of the glucocorticoid receptor. Nature. (2011) 480:552-6. doi: 10.1038/nature10700

100. Xu S, Liu Y, Hu R, Wang M, Stöhr O, Xiong Y, et al. TAZ inhibits GR and coordinates hepatic glucose homeostasis in normal physiologic states. bioRxiv. (2020). doi: 10.1101/2020.05.12.091264

101. Stortz M, Pecci A, Presman DM, Levi V. Unraveling the molecular interactions involved in phase separation of glucocorticoid receptor. $B M C$ Biol. (2020) 18:59. doi: 10.1186/s12915-020-00788-2

102. Hnisz D, Shrinivas K, Young RA, Chakraborty AK, Sharp PA. A phase separation model for transcriptional control. Cell. (2017) 169:1323. doi: 10.1016/j.cell.2017.02.007

103. Stavreva DA, Coulon A, Baek S, Sung MH, John S, Stixova L, et al. Dynamics of chromatin accessibility and long-range interactions in response to glucocorticoid pulsing. Genome Res. (2015) 25:84557. doi: 10.1101 /gr.184168.114

104. Hakim O, Sung MH, Voss TC, Splinter E, John S, Sabo PJ, et al. Diverse gene reprogramming events occur in the same spatial clusters of distal regulatory elements. Genome Res. (2011) 21:697-706. doi: 10.1101/gr.111153.110

105. Schule R, Muller M, Kaltschmidt C, Renkawitz R. Many transcription factors interact synergistically with steroid receptors. Science. (1988) 242:141820. doi: $10.1126 /$ science. 3201230

106. De Martino MU, Bhattachryya N, Alesci S, Ichijo T, Chrousos GP, Kino T. The glucocorticoid receptor and the orphan nuclear receptor chicken ovalbumin upstream promoter-transcription factor II interact with and mutually affect each other's transcriptional activities: implications for intermediary metabolism. Mol Endocrinol. (2004) 18:820-33. doi: 10.1210/me.2003-0341

107. Goldstein I, Baek S, Presman DM, Paakinaho V, Swinstead EE, Hager GL. Transcription factor assisted loading and enhancer dynamics dictate the hepatic fasting response. Genome Res. (2017) 27:427-39. doi: 10.1101/gr.212175.116

108. Everett LJ, Le Lay J, Lukovac S, Bernstein D, Steger DJ, Lazar MA, et al. Integrative genomic analysis of CREB defines a critical role for transcription factor networks in mediating the fed/fasted switch in liver. BMC Genomics. (2013) 14:337. doi: 10.1186/1471-2164-14-337

109. Zhang L, Rubins NE, Ahima RS, Greenbaum LE, Kaestner KH. Foxa2 integrates the transcriptional response of the hepatocyte to fasting. Cell Metab. (2005) 2:141-8. doi: 10.1016/j.cmet.2005.07.002

110. Hemmer MC, Wierer M, Schachtrup K, Downes M, Hubner N, Evans RM, et al. E47 modulates hepatic glucocorticoid action. Nat Commun. (2019) 10:306. doi: 10.1038/s41467-018-08196-5
111. Kuo T, Chen TC, Yan S, Foo F, Ching C, McQueen A, et al. Repression of glucocorticoid-stimulated angiopoietin-like 4 gene transcription by insulin. J Lipid Res. (2014) 55:919-28. doi: 10.1194/jlr.M047860

112. Nader N, Ng SS, Wang Y, Abel BS, Chrousos GP, Kino T. Liver $\mathrm{x}$ receptors regulate the transcriptional activity of the glucocorticoid receptor: implications for the carbohydrate metabolism. PLoS ONE. (2012) 7:e26751. doi: 10.1371/journal.pone.0026751

113. Patel R, Patel M, Tsai R, Lin V, Bookout AL, Zhang Y, et al. LXRbeta is required for glucocorticoid-induced hyperglycemia and hepatosteatosis in mice. J Clin Invest. (2011) 121:431-41. doi: 10.1172/JCI41681

114. Ratman D, Mylka V, Bougarne N, Pawlak M, Caron S, Hennuyer N, et al. Chromatin recruitment of activated AMPK drives fasting response genes co-controlled by GR and PPARalpha. Nucleic Acids Res. (2016) 44:1053953. doi: 10.1093/nar/gkw742

115. Murayama Y, Yahagi N, Takeuchi Y, Aita Y, Mehrazad Saber Z, Wada N, et al. Glucocorticoid receptor suppresses gene expression of Rev-erbalpha (Nr1d1) through interaction with the CLOCK complex. FEBS Lett. (2019) 593:423-32. doi: 10.1002/1873-3468.13328

116. Kriebs A, Jordan SD, Soto E, Henriksson E, Sandate CR, Vaughan ME, et al. Circadian repressors CRY1 and CRY2 broadly interact with nuclear receptors and modulate transcriptional activity. Proc Natl Acad Sci USA. (2017) 114:8776-81. doi: 10.1073/pnas.1704955114

117. Bailly A, Briançon N, Weiss MC. Characterization of glucocorticoid receptor and hepatocyte nuclear factor $4 \alpha(\mathrm{HNF} 4 \alpha)$ binding to the hnf $4 \alpha$ gene in the liver. Biochimie. (2009) 91:1095-103. doi: 10.1016/j.biochi.2009.06.009

118. Arenas F, Hervias I, ?riz M, Joplin R, Prieto J, Medina JF. Combination of ursodeoxycholic acid and glucocorticoids upregulates the AE2 alternate promoter in human liver cells. J Clin Invest. (2008) 118:695-709. doi: $10.1172 /$ JCI33156

119. Engblom D, Kornfeld JW, Schwake L, Tronche F, Reimann A, Beug H, et al. Direct glucocorticoid receptor-Stat 5 interaction in hepatocytes controls body size and maturation-related gene expression. Genes Dev. (2007) 21:115762. doi: $10.1101 / \operatorname{gad} .426007$

120. Tronche F, Opherk C, Moriggl R, Kellendonk C, Reimann A, Schwake L, et al. Glucocorticoid receptor function in hepatocytes is essential to promote postnatal body growth. Genes Dev. (2004) 18:492-7. doi: 10.1101/gad.284704

121. Freeman BC, Yamamoto KR. Disassembly of transcriptional regulatory complexes by molecular chaperones. Science. (2002) 296:2232. doi: 10.1126/science.1073051

122. Biddie SC, John S, Sabo PJ, Thurman RE, Johnson TA, Schiltz RL, et al. Transcription factor AP1 potentiates chromatin accessibility and glucocorticoid receptor binding. Mol Cell. (2011) 43:145-55. doi: 10.1016/j.molcel.2011.06.016

123. Sato S, Shirakawa H, Tomita S, Tohkin M, Gonzalez FJ, Komai M. The aryl hydrocarbon receptor and glucocorticoid receptor interact to activate human metallothionein 2A. Toxicol Appl Pharmacol. (2013) 273:909. doi: 10.1016/j.taap.2013.08.017

124. Wang SH, Liang CT, Liu YW, Huang MC, Huang SC, Hong $\mathrm{WF}$, et al. Crosstalk between activated forms of the aryl hydrocarbon receptor and glucocorticoid receptor. Toxicology. (2009) 262:87-97. doi: 10.1016/j.tox.2009.03.020

125. Fruchter O, Kino T, Zoumakis E, Alesci S, De Martino M, Chrousos $\mathrm{G}$, et al. The human glucocorticoid receptor (GR) isoform \{beta\} differentially suppresses GR\{alpha\}-induced transactivation stimulated by synthetic glucocorticoids. J Clin Endocrinol Metab. (2005) 90:35059. doi: 10.1210/jc.2004-1646

126. Bamberger CM, Bamberger AM, de Castro M, Chrousos GP. Glucocorticoid receptor beta, a potential endogenous inhibitor of glucocorticoid action in humans. J Clin Invest. (1995) 95:2435-41. doi: 10.1172/JCI117943

127. Scheschowitsch K, Leite JA, Assreuy J. New insights in glucocorticoid receptor signaling-more than just a ligand-binding receptor. Front Endocrinol. (2017) 8:16. doi: 10.3389/fendo.2017.00016

128. Marino JS, Stechschulte LA, Stec DE, Nestor-Kalinoski A, Coleman S, Hinds TD Jr. Glucocorticoid receptor beta induces hepatic steatosis by augmenting inflammation and inhibition of the peroxisome proliferatoractivated receptor (PPAR) alpha. J Biol Chem. (2016) 291:2577688. doi: 10.1074/jbc.M116.752311 
129. He B, Cruz-Topete D, Oakley RH, Xiao X, Cidlowski JA. Human glucocorticoid receptor beta regulates gluconeogenesis and inflammation in mouse liver. Mol Cell Biol. (2015) 36:714-30. doi: 10.1128/MCB.00908-15

130. Mueller KM, Kornfeld JW, Friedbichler K, Blaas L, Egger G, Esterbauer H, et al. Impairment of hepatic growth hormone and glucocorticoid receptor signaling causes steatosis and hepatocellular carcinoma in mice. Hepatology. (2011) 54:1398-409. doi: 10.1002/hep.24509

131. Pooley JR, Rivers CA, Kilcooley MT, Paul SN, Cavga AD, Kershaw $\mathrm{YM}$, et al. Beyond the heterodimer model for mineralocorticoid and glucocorticoid receptor interactions in nuclei and at DNA. PLoS ONE. (2020) 15:e0227520. doi: 10.1371/journal.pone.0227520

132. Mifsud KR, Reul JM. Acute stress enhances heterodimerization and binding of corticosteroid receptors at glucocorticoid target genes in the hippocampus. Proc Natl Acad Sci USA. (2016) 113:11336-41. doi: 10.1073/pnas.1605246113

133. Liu G, Grifman M, Keily B, Chatterton JE, Staal FW, Li QX. Mineralocorticoid receptor is involved in the regulation of genes responsible for hepatic glucose production. Biochem Biophys Res Commun. (2006) 342:1291-6. doi: 10.1016/j.bbrc.2006.02.065

134. Phair RD, Scaffidi P, Elbi C, Vecerova J, Dey A, Ozato K, et al. Global nature of dynamic protein-chromatin interactions in vivo: three-dimensional genome scanning and dynamic interaction networks of chromatin proteins. Mol Cell Biol. (2004) 24:6393-402. doi: 10.1128/MCB.24.14.63936402.2004

135. Voss TC, Schiltz RL, Sung MH, Yen PM, Stamatoyannopoulos JA, Biddie SC, et al. Dynamic exchange at regulatory elements during chromatin remodeling underlies assisted loading mechanism. Cell. (2011) 146:54454. doi: 10.1016/j.cell.2011.07.006

136. Wang Q, Blackford JA Jr, Song LN, Huang Y, Cho S, Simons SS Jr. Equilibrium interactions of corepressors and coactivators with agonist and antagonist complexes of glucocorticoid receptors. Mol Endocrinol. (2004) 18:1376-95. doi: 10.1210/me.2003-0421

137. Præstholm SM, Siersbæk MS, Nielsen R, Zhu X, Hollenberg AN, Cheng S-y, et al. Multiple mechanisms regulate $\mathrm{H} 3$ acetylation of enhancers in response to thyroid hormone. PLOS Genetics. (2020) 16:e1008770. doi: 10.1371/journal.pgen.1008770

138. Reddy AB, Maywood ES, Karp NA, King VM, Inoue Y, Gonzalez FJ, et al. Glucocorticoid signaling synchronizes the liver circadian transcriptome. Hepatology. (2007) 45:1478-88. doi: 10.1002/hep.21571

139. Yamamoto T, Nakahata Y, Tanaka M, Yoshida M, Soma H, Shinohara K, et al. Acute physical stress elevates mouse period1 mRNA expression in mouse peripheral tissues via a glucocorticoid-responsive element. J Biol Chem. (2005) 280:42036-43. doi: 10.1074/jbc.M509600200

140. Lu Y, Xiong X, Wang X, Zhang Z, Li J, Shi G, et al. Yin Yang 1 promotes hepatic gluconeogenesis through upregulation of glucocorticoid receptor. Diabetes. (2013) 62:1064-73. doi: 10.2337/db12-0744

141. Cui A, Fan H, Zhang Y, Zhang Y, Niu D, Liu S, et al. Dexamethasoneinduced Kruppel-like factor 9 expression promotes hepatic gluconeogenesis and hyperglycemia. J Clin Invest. (2019) 129:2266-78. doi: 10.1172/JCI66062

142. Li R, Jia Y, Pan S, Li X, Song H, Zhao R. Glucocorticoid receptor mediates the effect of high-fat diet on mitochondrial oxidative phosphorylation in mouse liver. DNA Cell Biol. (2016) 35:51-8. doi: 10.1089/dna.2015.2932

143. Okun JG, Conway S, Schmidt KV, Schumacher J, Wang X, de Guia R, et al. Molecular regulation of urea cycle function by the liver glucocorticoid receptor. Mol Metab. (2015) 4:732-40. doi: 10.1016/j.molmet.2015.07.006

144. Rose AJ, Berriel Diaz M, Reimann A, Klement J, Walcher T, Krones-Herzig A, et al. Molecular control of systemic bile acid homeostasis by the liver glucocorticoid receptor. Cell Metab. (2011) 14:123-30. doi: 10.1016/j.cmet.2011.04.010

145. Bose SK, Hutson I, Harris CA. Hepatic glucocorticoid receptor plays a greater role than adipose GR in metabolic syndrome despite renal compensation. Endocrinology. (2016) 157:4943-60. doi: 10.1210/en.2016-1615
146. Opherk C, Tronche F, Kellendonk C, Kohlmüller D, Schulze A, Schmid $\mathrm{W}$, et al. Inactivation of the glucocorticoid receptor in hepatocytes leads to fasting hypoglycemia and ameliorates hyperglycemia in streptozotocin-induced diabetes mellitus. Mol Endocrinol. (2004) 18:1346-53. doi: 10.1210/me.2003-0283

147. Langlet F, Haeusler RA, Linden D, Ericson E, Norris T, Johansson A, et al. Selective inhibition of FOXO1 activator/repressor balance modulates hepatic glucose handling. Cell. (2017) 171:824-35.e18. doi: 10.1016/j.cell.2017.09.045

148. Chen J, Zhang Z, Wang N, Guo M, Chi X, Pan Y, et al. Role of HDAC9-FoxO1 axis in the transcriptional program associated with hepatic gluconeogenesis. Sci Rep. (2017) 7:6102. doi: 10.1038/s41598-017-06328-3

149. Bougarne N, Weyers B, Desmet SJ, Deckers J, Ray DW, Staels B, et al. Molecular actions of PPARalpha in lipid metabolism and inflammation. Endocr Rev. (2018) 39:760-802. doi: 10.1210/er.2018-00064

150. Bougarne N, Paumelle R, Caron S, Hennuyer N, Mansouri R, Gervois P, et al. PPARalpha blocks glucocorticoid receptor alpha-mediated transactivation but cooperates with the activated glucocorticoid receptor alpha for transrepression on NF-kappaB. Proc Natl Acad Sci USA. (2009) 106:7397402. doi: 10.1073/pnas.0806742106

151. Baik M, Yu JH, Hennighausen L. Growth hormone-STAT5 regulation of growth, hepatocellular carcinoma, and liver metabolism. Ann N Y Acad Sci. (2011) 1229:29-37. doi: 10.1111/j.1749-6632.2011.06100.x

152. Wu T, Jiang J, Yang L, Li H, Zhang W, Chen Y, et al. Timing of glucocorticoid administration determines severity of lipid metabolism and behavioral effects in rats. Chronobiol Int. (2017) 34:78-92. doi: 10.1080/07420528.2016.1238831

153. Delezie J, Dumont S, Dardente H, Oudart H, Grechez-Cassiau A, Klosen $\mathrm{P}$, et al. The nuclear receptor REV-ERBalpha is required for the daily balance of carbohydrate and lipid metabolism. FASEB J. (2012) 26:332135. doi: 10.1096/fj.12-208751

154. Zhang Y, Fang B, Emmett MJ, Damle M, Sun Z, Feng D, et al. GENE REGULATION. Discrete functions of nuclear receptor Reverbalpha couple metabolism to the clock. Science. (2015) 348:148892. doi: $10.1126 /$ science.aab3021

155. Zhang Y, Fang B, Damle M, Guan D, Li Z, Kim YH, et al. HNF6 and Rev-erbalpha integrate hepatic lipid metabolism by overlapping and distinct transcriptional mechanisms. Genes Dev. (2016) 30:163644. doi: $10.1101 / \operatorname{gad} .281972 .116$

156. Torra IP, Tsibulsky V, Delaunay F, Saladin R, Laudet V, Fruchart JC, et al. Circadian and glucocorticoid regulation of Rev-erbalpha expression in liver. Endocrinology. (2000) 141:3799-806. doi: 10.1210/endo.141.10.7708

157. Greulich F, Hemmer MC, Rollins DA, Rogatsky I, Uhlenhaut NH. There goes the neighborhood: assembly of transcriptional complexes during the regulation of metabolism and inflammation by the glucocorticoid receptor. Steroids. (2016) 114:7-15. doi: 10.1016/j.steroids.2016.05.003

158. Buttgereit F, Doering G, Schaeffler A, Witte S, Sierakowski S, GromnicaIhle E, et al. Efficacy of modified-release versus standard prednisone to reduce duration of morning stiffness of the joints in rheumatoid arthritis (CAPRA-1): a double-blind, randomised controlled trial. Lancet. (2008) 371:205-14. doi: 10.1016/S0140-6736(08)60132-4

Conflict of Interest: The authors declare that the research was conducted in the absence of any commercial or financial relationships that could be construed as a potential conflict of interest.

Copyright (C) 2020 Prostholm, Correia and Grøntved. This is an open-access article distributed under the terms of the Creative Commons Attribution License (CC BY). The use, distribution or reproduction in other forums is permitted, provided the original author(s) and the copyright owner(s) are credited and that the original publication in this journal is cited, in accordance with accepted academic practice. No use, distribution or reproduction is permitted which does not comply with these terms. 